\title{
Histological Study on the Possible Protective Role of Moringa Oleifera Leaves Extract on Paracetamol Induced Liver Damage in Adult Male Albino Rats
} Original Article

\author{
Dina M. El Morsey, Naglaa M. Abou-Rabia, Gehan Khalaf and Samar F. Ezzat
}

Department of Histology and Cell Biology, Faculty of Medicine, Ain Shams University

\begin{abstract}
Introduction: Moringa oleifera is a tropical tree whose leaves are rich in antioxidant compounds. Paracetamol hepatotoxicity is a significant public health concern.

Aim: The aim of this study was to investigate the possible protective role of Moringa oleifera leaves (MOL) aqueous extract on paracetamol induced liver injury in adult male albino rats.

Materials and Methods: Forty adult male albino rats were used in the current study and were divided into four equal groups,: Group I served as control; Group II were given MOL for 14 days; Group III were given water for 7 days followed by paracetamol for another seven days; Group IV were given MOL for 14 days and Paracetamol on the seventh day for 7days.All medications were given by nasogastric tube. Specimens of liver were excised and processed for histological and histochemical studies. Blood samples were collected for biochemical study. Statistical analysis of the results was done.

Results: MOL administration in group II didn't affect hepatic architecture or liver function tests. There was a significant increase in glutathione peroxidase and catalase activity and no significant difference in malondialdehyde level as compared to control. Paracetamol administration led to vacuolization of hepatocytes, cellular infiltrations and congestion in central and portal veins, with apparent increase in number of cholangiocytes. There were also significant decrease in the area percentage of PAS positive granules and significant decrease in area percentage of collagen fibers as compared to control. By electron microscope, distorted mitochondria, decrease of rough endoplasmic reticulum and increase of smooth endoplasmic reticulum \& collagen fibrils were observed. Administration of Moringa before paracetamol ameliorated damaging effects of paracetamol. Minimal cellular infiltrations and apparent increase in number of cholangiocytes were still observed.

Conclusion: MOL extracts could protect the liver against paracetamol effects through inhibition of lipid peroxidation and enhancement of antioxidant enzymes.
\end{abstract}

Received: 15 January 2019, Accepted: 28 March 2019

Key Words: Histopathology, liver, moringa oleifera, paracetamol.

Corresponding Author: Samar F. Ezzat, MD, Histology and Cell Biology Department, Faculty of Medicine, Ain Shams University, Cairo, Egypt, Tel.: +20 1001842765, E-mail: samarezzatali@yahoo.com

ISSN: 1110-0559, Vol. 42, No. 3

\section{INTRODUCTION}

Liver plays an important role in biotransformation of drugs and toxins, so the drug induced hepatotoxicity should be a major concern in drug development and chronic drug therapy ${ }^{[1]}$. More than 900 drugs have been found to cause liver injury and this is the most common reason for a drug withdrawal from the market ${ }^{[2]}$.

Natural medications from plants are considered as effective and safe alternative treatments for hepatotoxicity ${ }^{[3]}$. Plants have thus been investigated for hepatoprotective and antioxidant effects against hepatotoxin induced liver damage ${ }^{[4]}$. Previous studies have shown that hepatoprotective effects are usually due to the presence of phytocompounds rich in natural antioxidants ${ }^{[3]}$.

Moringa oleifera is an evergreen tree ${ }^{[5]}$ whose edible parts have been used for homeopathic aspects since ancient times ${ }^{[6]}$. Although being native to Africa ${ }^{[7]}$, such a use is not known by the public ${ }^{[8]}$.It was known along the Nile valley by the name of 'Shagara al Rauwaq', which means 'tree for purifying ${ }^{[9]}$. Many organizations are promoting for its uses as an untapped opportunity ${ }^{[10]}$.

Recently Moringa oleifera is coming to the forefront as a result of scientific evidence that Moringa is an important source of naturally occurring phytochemicals ${ }^{[11]}$. Phytochemical analyses have shown that its leaves are rich in potassium, calcium, phosphorous, iron, vitamins A and $\mathrm{D}$, essential amino acids, as well as known antioxidants such as $\beta$-carotene, vitamin $\mathrm{C}$, and flavonoids ${ }^{[12]}$.

Paracetamol was first introduced as an analgesic in 1893, yet was not popular until the 1960s, after knowing that phenacetin, a frequently used analgesic in those days, was nephrotoxic in chronic abusers ${ }^{[13]}$. Nowadays, paracetamol has become more popular due to the increased concern about aspirin mediated gastrointestinal bleeding and Rye's syndrome. According to the US Food and Drug 
Administration, each week approximately 50 million adults in the United States take paracetamol containing products. Today, paracetamol toxicity accounts for $50 \%$ of all cases of acute liver failure in the United States and Great Britain ${ }^{[14]}$. Annually, it accounts for a high percentage of the admissions to the poison control centers and also for the deaths ${ }^{[15]}$. The United States spend about $\$ 87$ million dollars annually in treatment of paracetamol induced hepatotoxicity ${ }^{[16]}$. Paracetamol over dose is the most common cause of drug induced hepatotoxicity worldwide ${ }^{[1]}$ and its side effects are multiplied when given to chronic liver patients ${ }^{[17]}$.

Previous studies showed that Moringa oleifera extract could protect the liver tissue against the induced hepatotoxicity by enhancing the antioxidant defense system $^{[18]}$. The anti hepatotoxic nature of Moringa oleifera leaves aqueous extract against paracetamol induced liver injury in rats has not been fully investigated, therefore the target of the present work is to study the hepatoprotective role of Moringa oleifera leaves extract on paracetamol induced liver injury.

\section{AIM}

This study aimed to investigate the possible protective role of Moringa oleifera leaves aqueous extract on paracetamol induced liver injury in adult male albino rats.

\section{MATERIALS AND METHODS}

\section{Animals}

Forty adult male albino rats (4-5 months) with an average weight ranged from 200 to 250 grams were housed in wire mesh cages and were freely allowed to a chow diet and water ad libtum. The experiment was conducted in the scientific research center at Ain Shams University. Animals were kept for seven days before the beginning of the experiment for acclimatization. All animal procedures were carried out according to the recommendation of the institutional animal ethics committee at the faculty of Medicine, Ain Shams University. The animals were divided into four equal groups, ten rats each.

Group I, Control group in which rats received $0.5 \mathrm{ml}$ of water by nasogastric tube for 14 days.

Group II, Moringa Oleifera group: rats were given Moringa oleifera leaves aqueous extract $(500 \mathrm{mg} / \mathrm{kg}$ body weight) by nasogastric tube for 14 days $^{[19]}$.

Group III: Paracetamol group: rats received water by nasogastric tube for 7 days then received paracetamol ( $400 \mathrm{mg} / \mathrm{kg}$ body weight) that was given by nasogastric tube on the seventh day for another seven days.

Group IV, Moringa Oleifera and paracetamol group: rats were given Moringa oleifera leaves aqueous extract (500 mg/kg body weight) by nasogastric tube for 14 days and Paracetamol (400 mg/kg body weight) by nasogastric tube on the seventh day for seven days.

\section{Preparation of plant extract}

The plant materials are harvested in Cairo - Alexandria desert road, Egypt and purchased from Pure Life co. Egypt). The plant aqueous extract was prepared by mixing $1 \mathrm{gm}$ of dried and powdered leaves of Moringa olifeira with $10 \mathrm{ml}$ boiling water for 5 minutes. The mixture was then filtered twice through $2 \mu \mathrm{m}$ pore sterile filter paper into a sterile tube. The aqueous extract stock solution $(100 \mathrm{mg} / \mathrm{ml})$ was freshly prepared for each set of experiment and stored at $4^{\mathrm{o}} \mathrm{c}$ for up to 5 days ${ }^{[20]}$.

\section{The drug}

Paracetamol was purchased as Cetal $100 \mathrm{mg} / \mathrm{ml}$ and given orally by nasogastric tube. Dose of $400 \mathrm{mg} / \mathrm{kg}$ body weight, equivalent to $40 \mathrm{mg} / 100 \mathrm{gm}$ body weight (which is equivalent to the maximum therapeutic dose in human), was prepared to be given to group III later ${ }^{[21]}$.

On day 15 the rats were fasted, then anaesthetized, blood was collected via cardiac puncture then the animals were sacrificed by cervical dislocation. The Liver specimens were excised and processed to obtain paraffin blocks Sections of $5 \mu \mathrm{m}$ thickness were cut and stained with the following:

1. Hematoxylin and Eosin (H\&E) stain

2. Masson'strichrome stain

3. Periodic Acid Schiff's reaction (PAS).

Also, small pieces of liver tissue were rapidly fixed and then processed for Transmission electron microscopic study (TEM). Specimens were examined and photographed with JEOL- 1010 Transmission electron microscope made in Japan at EM unit at the Regional Center of Mycology and Biotechnology, Azhar University, Cairo, Egypt.

\section{Morphometric study}

Mean area \% of glycogen granules in hepatocytes and mean area $\%$ of the green stained collagen fibers in Masson's trichrome stained sections were measured. This was performed in five non-overlapping fields from five different sections of ten different rats in each group using image analyzer Leica QwinV.3 Program connected to a camera (DM2500, Leica microsystems, Wetzlar, Germany) at the Histology Department, Faculty of Medicine, Ain shams University.

\section{Biochemical study}

At time of sacrifice blood samples were collected to measure Aspartate transaminase (AST), Alanine transaminase (ALT) and Alkaline phosphatase (ALP). They were assessed in the lab of biochemistry department at Ain Shams university using diagnostic kits purchased from Roche Diagnostic Ltd (Germany). 


\section{Oxidative state of liver tissue was investigated}

Four to five $\mathrm{mm}$ slices of liver tissue were rapidly stored at $-80^{\circ} \mathrm{C}$ to be processed and handled to prepare tissue homogenate.

Liver was weighed and homogenized in ice cold 0.15 M Tris-KCL (0.15M KCL+10mM Tris-HCl, PH7.4). The homogenate was then centrifuged at $600 \mathrm{~g}$ for $10 \mathrm{~min}$. Supernatant was collected and centrifuged again at 10,000 $\mathrm{g}$ for $30 \mathrm{~min}^{[22]}$.

Tissue Malondialdehyde, tissue Glutathione peroxidase (GSHPx), and tissue Catalase were estimated as follows:

MDA level was measured by thiobarbituric acid test ${ }^{[23]}$. Activity of Glutathione Peroxidase enzyme (GSHPx) level was estimated by commercial kinetic method kits (The Glutathione Peroxidase UV method Activity Assay kit) purchased from Bio-Diagnostic, Egypt according to the instructions of the manufacturer. Activity of Catalase level was estimated by commercial kinetic method kits (Catalase Assay, Colorimetric method) purchased from Bio-Diagnostic, Egypt according to the instructions of the manufacturer.

\section{Statistical analysis}

All data of morphometric and biochemical analysis were collected, revised and then subjected to statistical analysis using one-way Analysis of Variance (ANOVA) method to test the mean differences observed among the four different groups. The test was performed by SPSS package (version 23 for Windows). P. value less than 0.05 was considered significant.

\section{RESULTS}

\section{Histological results}

H\&E stained liver section of rats from Group I showed that liver parenchyma consists of branching and anastomosing cords of hepatocytes radiating from the central vein. Blood sinusoids separating hepatic cords were lined by flat endothelial cells and Kupffer cells. The polygonal hepatocytes had acidophilic cytoplasm with basophilic bodies and single, central, rounded vesicular nucleus of variable size with prominent nucleoli. Some cells appeared binucleated (Figure 1). Branches of hepatic artery, portal vein and bile ducts could be seen at the portal tracts (Figure 2). Examination of liver sections of rats from group II showed that they were nearly similar to those of group I.

In group III, Paracetamol led to mononuclear cellular infiltrations in some areas within the hepatic lobules. Most of the hepatocytes surrounding the congested central vein appeared with vacuolated cytoplasm. Some vacuolated hepatocytes appeared with rounded vesicular nuclei (Figure 3), while others showed shrunken, irregular and darkly stained nuclei. Blood sinusoids were hardly visible between the ballooned hepatocytes (Figure 4). Cellular infiltrations close to congested and dilated portal vein branch were also detected (Figure 5). Portal area showed an apparent increase in the number of the lining cells of bile ductules as compared to that of the control group. The hepatocytes around portal area were vacuolated (Figure 6).

While, examination of liver sections of rats of Group IV showed that the structure of liver was comparable to that of the control group. Branching and anastomosing cords of polygonal hepatocytes with vesicular nuclei were seen radiating from the central vein. Few cells showed small dark nuclei. The cytoplasm of the hepatocytes was hardly vacuolated in comparison to paracetamol group. The blood sinusoids could be clearly seen between the hepatocytes. They were lined by endothelial cells and Kupffer cells (Figure 7). Portal area showed minimal cellular infiltration. However, apparent increase in number of cells lining bile ductules within the portal area and the nearby bile canaliculi at the periphery of the hepatic lobules was noticed in some sections (Figure 8).

On examination of Liver sections stained with PAS, most of the hepatocytes in group I (Figure 9) and group II had PAS positive glycogen granules in their cytoplasm. While in group III, patchy distribution of PAS negative hepatocytes was noticed with an apparent decrease in the PAS positive glycogen granules, compared with group I (Figure 10). In group IV, the PAS positive glycogen granules in the hepatocytes were almost similar to that of the control group (Figure 11).

Liver sections stained with Masson's trichrome stain revealed minimal amount of green stained collagen fibers surrounding the central vein and portal areas and in between hepatocytes in group I (Figures $12 \mathrm{a} \& \mathrm{~b}$ ) and group II. While, In group III apparent increase in collagen fibers was noticed around the central vein and the portal area with appearance of collagen fibers running between and surrounding the hepatocytes (Figures $13 \mathrm{a} \& \mathrm{~b}$ ). In group IV, the collagen fibers content in the portal tracts and around the central vein was almost similar to that in control group (Figures $14 \mathrm{a} \& \mathrm{~b}$ ).

Electron microscopic examination of the control group revealed that hepatocytes have central rounded euchromatic nuclei surrounded by nuclear membrane. The cytoplasm showed numerous mitochondria variable in shape, with cristae. The mitochondria appeared associated with rough endoplasmic reticulum (rER). Rosettes of glycogen granules scattered in cytoplasm were also seen (Figure 15). Bile canaliculi in between adjacent hepatocytes were obvious, with short microvilli from the hepatocytes surface were projecting into their lumina. Close to the canaliculi junctional complexes were seen attaching hepatocytes to each other (Figure 16). Hepatic stellate cells (HSCs, Ito cells, stellate fat storing cells) lying in between hepatocytes were detected. HSC had elongated nucleus and multiple lipid droplets in its cytoplasm (Figure 17). The ultra structure of the hepatocytes in group II was nearly similar to that of the control group. 
In Group III, electron microscopic examination showed that some of the hepatocytes had vacuolated cytoplasm and shrunken, irregular nucleus with more peripheral heterochromatin. Small lipid droplets of variable size with well-defined edges were seen in the cytoplasm. Apparent decrease in the mitochondria and rough endoplasmic reticulum was noticed as compared to that of the control group (Figure 18). On the other hand, some hepatocytes showed elongated distorted mitochondria and numerous profiles of smooth endoplasmic reticulum (sER) as compared to that of the control group (Figure 19). Other sections showed adjacent hepatocytes with lipid droplets of variable size with well-defined edges scattered in the cytoplasm. Collagen fibrils in between the hepatocytes were noticed (Figure 20). Microvilli projecting into the lumen of the bile canaliculi were apparently shorter and lacking in some sites when compared to that of the control group. Close to the canaliculi junctional complexes were seen attaching hepatocytes to each other. Elongated mitochondria were evident (Figure 21). HSC in association with collagen fibrils were frequently seen. They appeared elongated and their cytoplasm was nearly devoid of lipid droplets as compared to that of the control group (Figure 22).

Electron microscopic examination of the liver in Group IV, showed hepatocytes containing euchromatic nuclei. Their cytoplasm contained many mitochondria with apparent cristae. Rough endoplasmic reticulum and glycogen granules were also seen (Figure 23). Bile canaliculi showed microvilli projecting into their lumina. Cell membranes of the adjacent hepatocytes were attached to each other by junctional complexes close to the canaliculus (Figure 24). Hepatic stellate cells have euchromatic nuclei and multiple lipid droplets in their cytoplasm. No collagen fibrils were noticed in between hepatocytes (Figure 25).

\section{Statistical results}

\section{Morphometric parameters}

Area percentage of glycogen granules was significantly decreased in group III as compared to that of the other groups. There was no significance difference of area percentage of glycogen granules in group I, group II or group IV (Table 1).

Area percentage of collagen fibers was significantly increased in group III as compared to that of the other groups. There was no significance difference of area percentage of collagen fibers in the control group (Group I), group II or group IV (Table 2)

\section{Biochemical parameters}

Serum ALT, AST and ALP Levels were significantly elevated after paracetamol administration, in group III as compared to that of the control group. In group IV,
ALT, AST and ALP levels were significantly reduced as compared to that of group III. While there was no significant difference in the level of serum ALT, AST and ALP of the control group, group II and group IV (Table 3).

Tissue MDA was significantly increased in group III as compared to that of the other groups. There was no significance difference of the tissue MDA level in group I, group II or group IV (Table 4).

The level of Tissue GSHPx and catalase were significantly increased in group II as compared to that of the control group. Paracetamol administration in group III produced a significant decrease in the level of tissue GSHPx and catalase as compared to that of the other groups. Group IV showed non significant difference in the level of GSHPx and catalase as compared to that of the control group (Table 5).

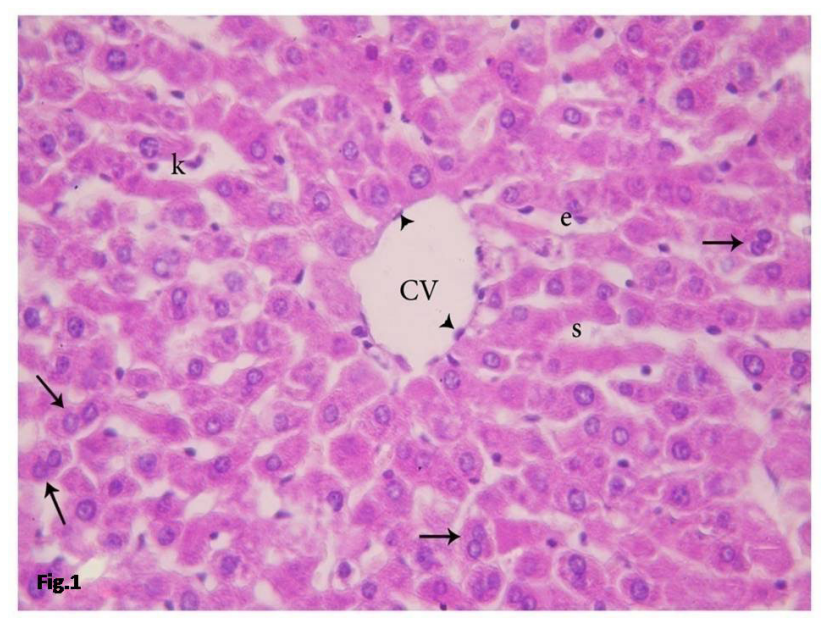

Fig. 1: A photomicrograph showing a section of rat liver, central vein $(\mathrm{CV})$ appeared lined by flat endothelial cells $(\boldsymbol{\Delta})$, surrounded by cords of polygonal hepatocytes with granular cytoplasm central, rounded, vesicular nuclei. Some cells appear binucleated $(\uparrow)$. Blood sinusoids (s) are lined by flat endothelial cells (e) and Kupffer cells (k). Group I (control group), H\&E x 400

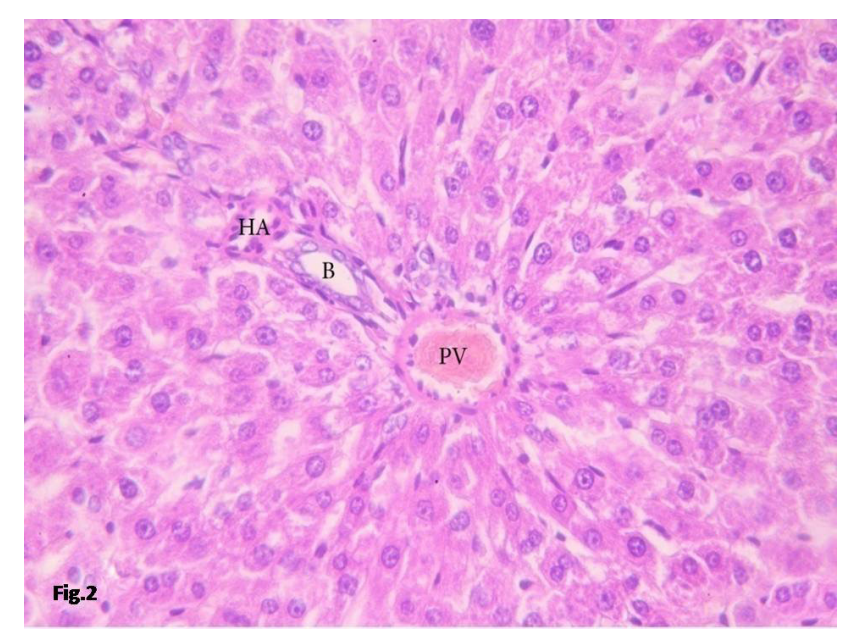

Fig. 2: branches of portal vein (PV), hepatic artery (HA) and bile ductule (B) are seen at a portal tract. Group I H\&E x 400 


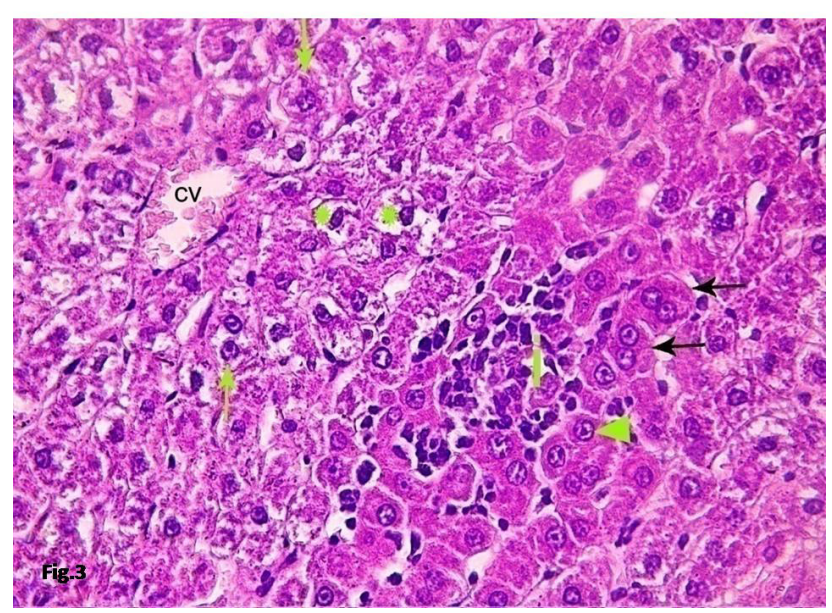

Fig. 3: Showing swollen hepatocytes with vacuolated cytoplasm and rounded vesicular nuclei (green arrow $\uparrow$ ). Some nuclei are darkly stained (*). Other hepatocytes appear with acidophilic cytoplasm and vesicular nucleus (green arrow head $\boldsymbol{\Delta}$ ). Cellular infiltration (i) is seen inclose proximity to the congested central vein (CV). Group III, H\&E x 400

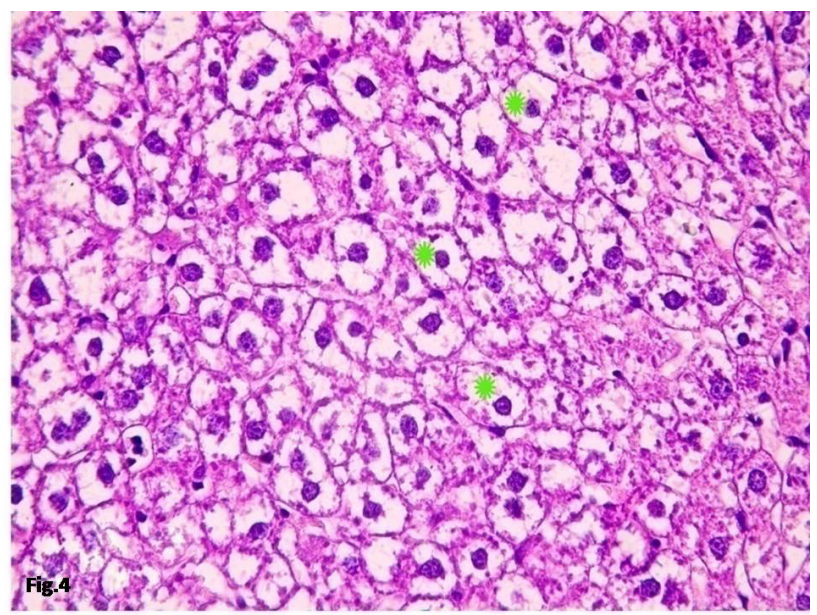

Fig. 4: Swollen hepatocytes with highly vacuolated cytoplasm(*) and shrunken, irregular and darkly stained nuclei are noticed. Blood sinusoids are hardly visible between the ballooned hepatocytes. Group III, H\&E x 400

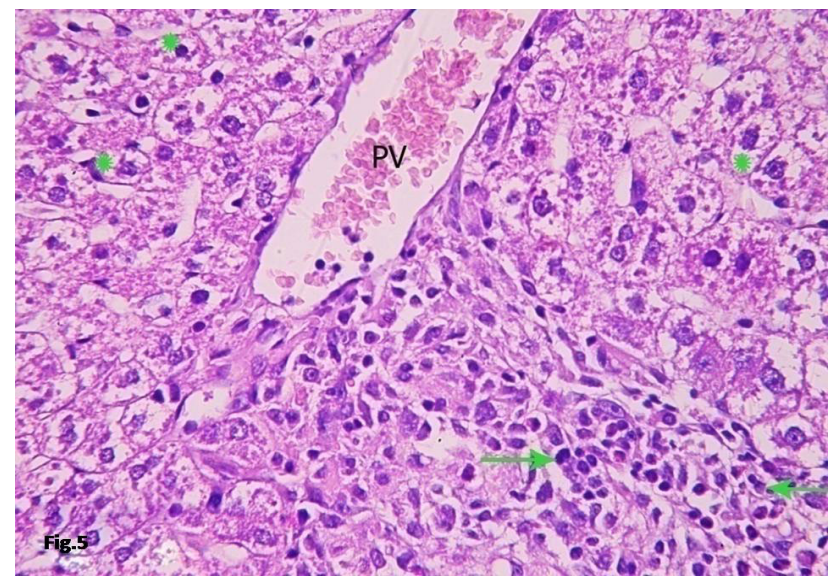

Fig. 5: Swollen hepatocytes with highly vacuolated cytoplasm $\left(^{*}\right)$ with shrunken, irregular and darkly stained nuclei are seen. Note the congested and dilated portal vein branch (PV) with nearby cellular infiltrations ( $\uparrow$ ). Group III, H\&Ex400

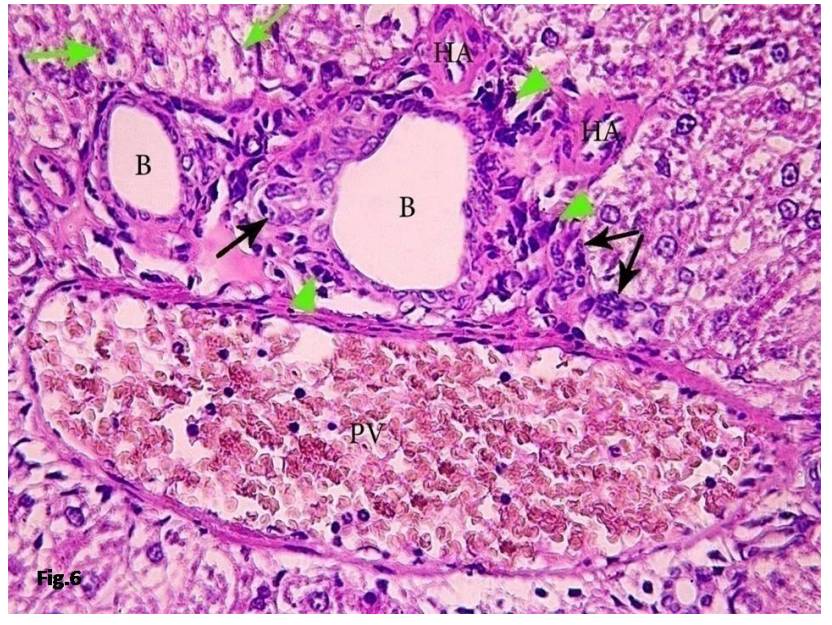

Fig. 6: Apparent increase in the number of lining cells (black arrow $\uparrow$ ) of bile ductule (B) as compared to that of the control group is detected. Portal vein (PV) branch is dilated and congested. Note cellular infiltration (green arrow head $\mathbf{\Delta}$ ) within the portal area. Vacuolated hepatocytes around portal area also seen (green arrow $\uparrow$ ). Group III H\&E x 400

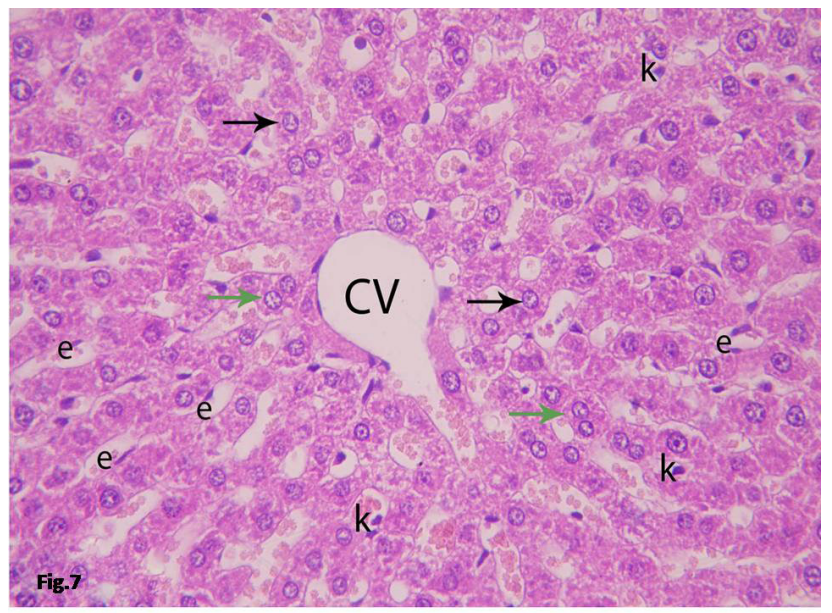

Fig. 7: Hepatocytes appeared polygonal with acidophilic cytoplasm and vesicular nuclei $(\uparrow)$ nearly similar to the control. Binucleated cells are seen (green arrow $\uparrow$ ). The blood sinusoids are lined by endothelial cells (e) and Kupffer cells (k). Group IV, H\&E x 400

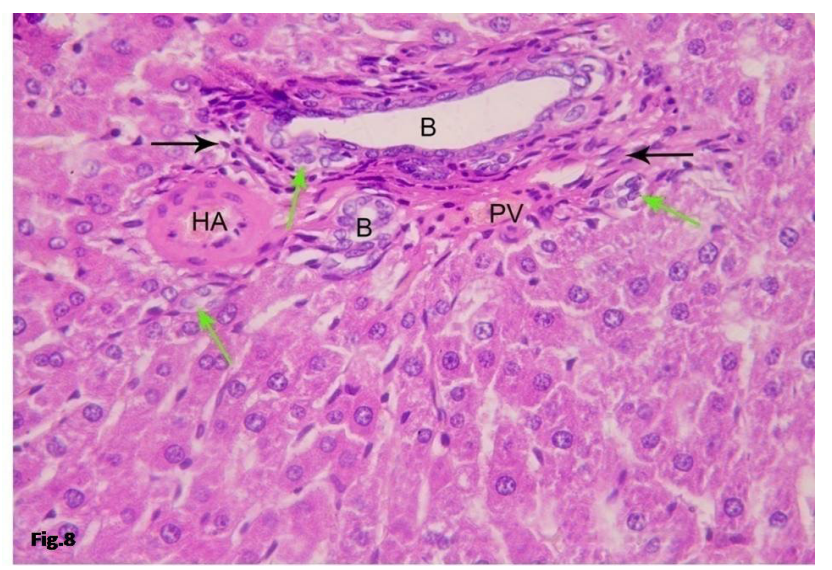

Fig. 8: Shows portal area with minimal cellular infiltration ( $\uparrow)$. Notice the apparent increase in number of cells lining bile ductule and nearby bile canaliculi (green arrow $\uparrow$ ). Note hepatic artery branch (HA), Portal vein branch (PV) and bile ductules (B). Group IV, H\&E x 400 


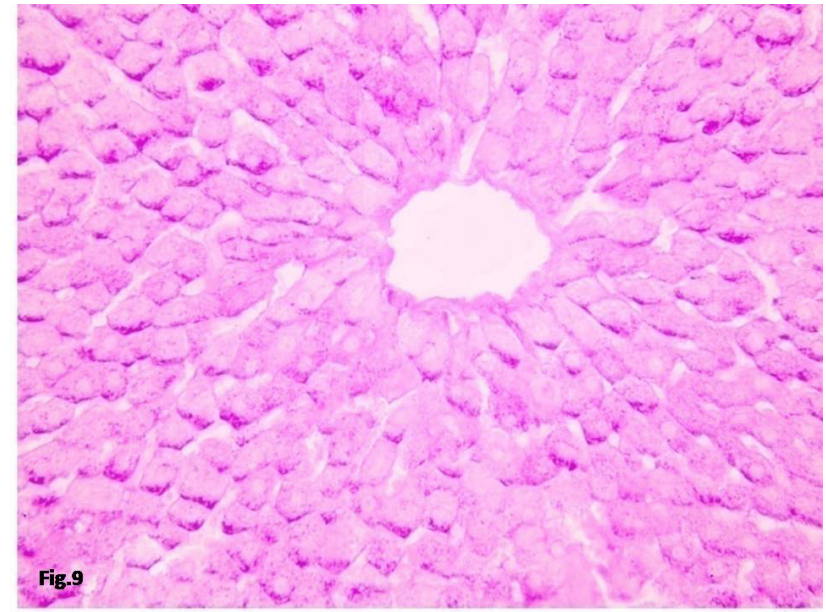

Fig. 9: PAS positive granules are prominent within the cytoplasm of most of hepatocytes. Group I, PAS x 400

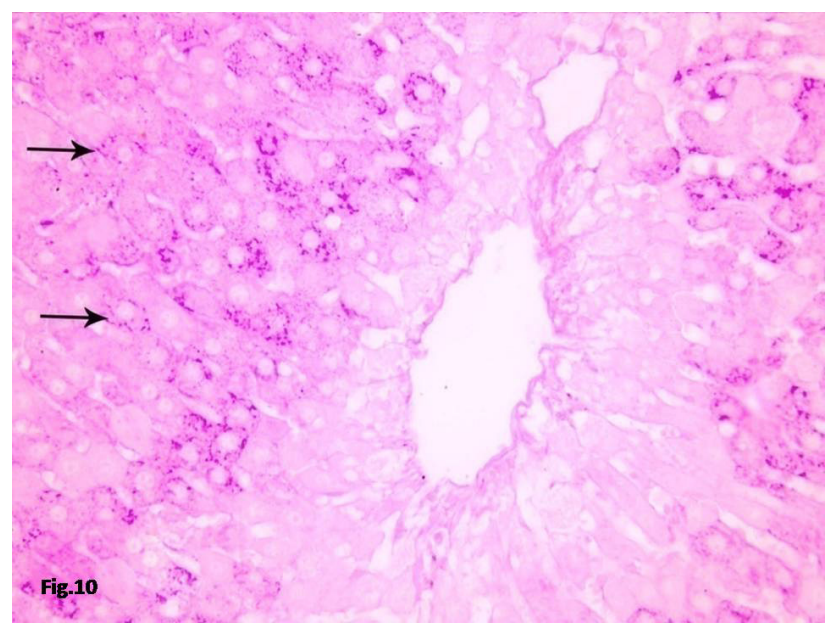

Fig. 10: Hepatocytes appeared with a decrease in the PAS positive glycogen granules $(\uparrow)$ as compared to that of the control. Group III, PAS x 400

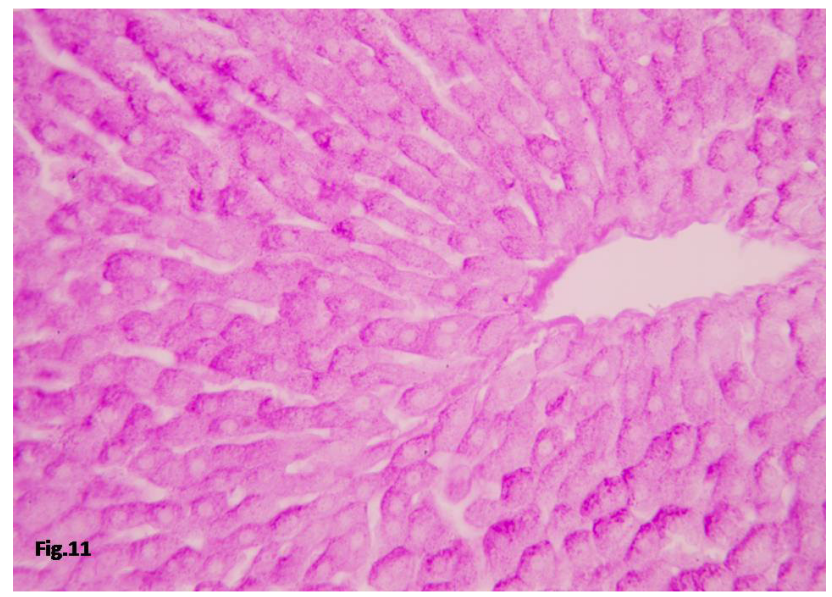

Fig. 11: PAS positive glycogen granules appeared within the cytoplasm of most of hepatocytes similar to the control. Group IV, PAS x 400
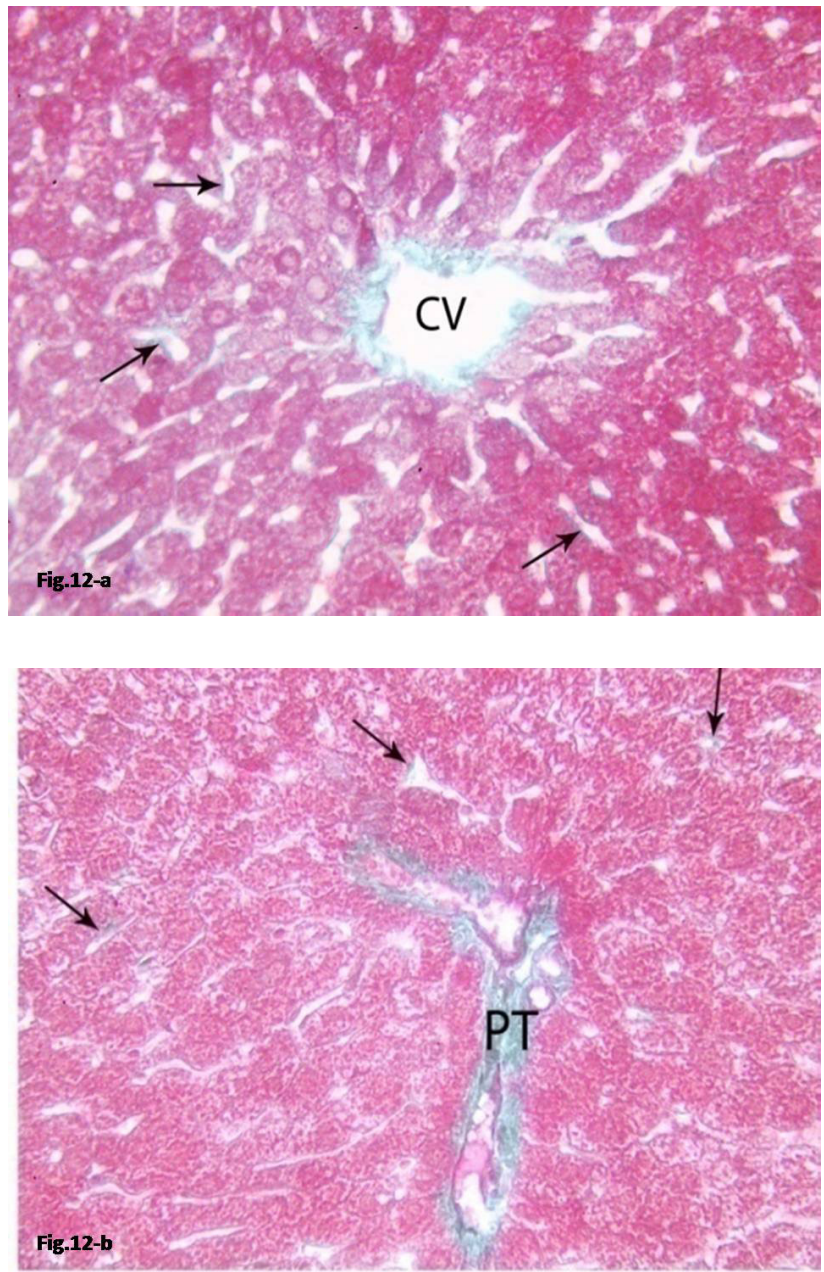

Fig. 12: (a\&b) Showing minimal amount of green stained collagen fiber surrounding the central vein $(\mathrm{CV})$ [a], within perisinusoidal spaces $(\uparrow)$ $[\mathrm{a} \& \mathrm{~b}]$ and in the portal tract (PT) [b]. Group I, Masson's trichrome x 400

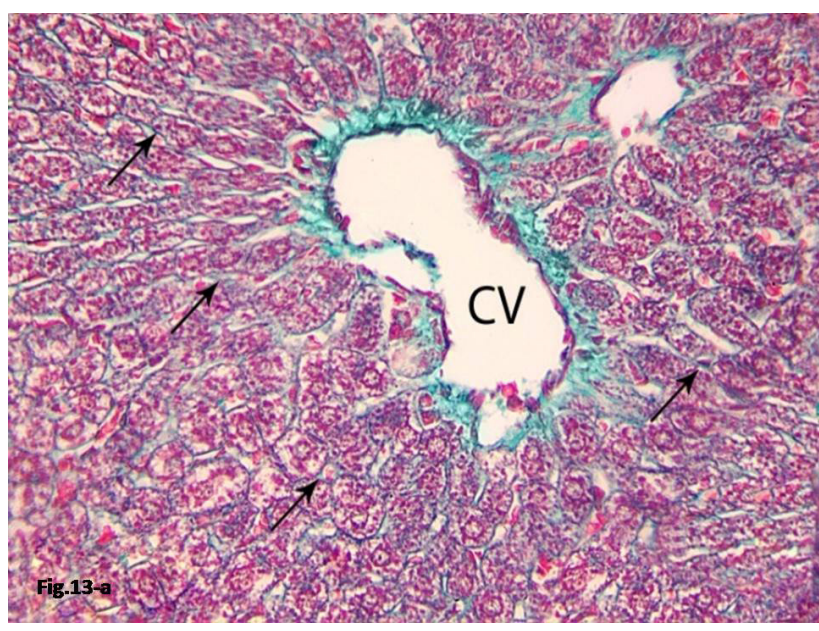

Continued 


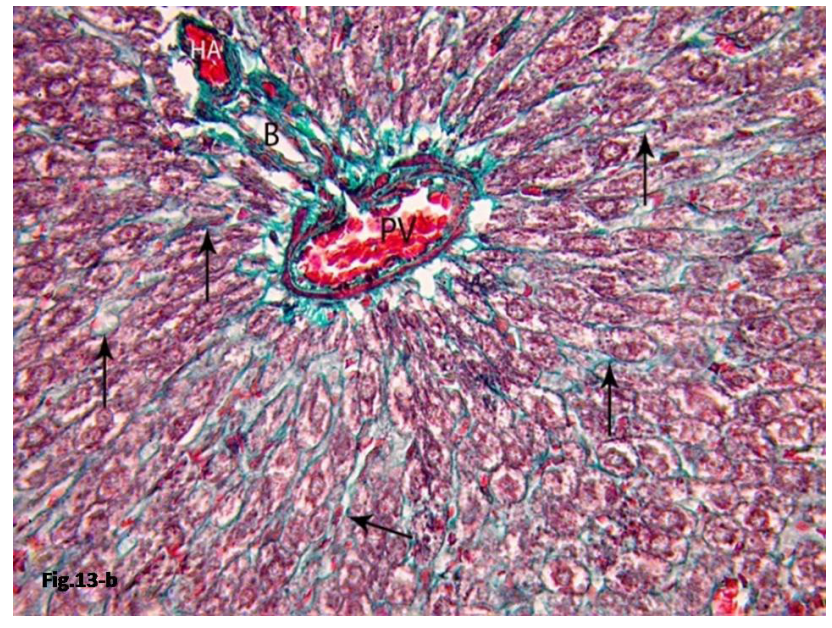

Fig. 13: $(a \& b)$. Apparent increase in green stained collagen fibers around the central vein $(\mathrm{CV})[\mathrm{a}]$ and the portal area [b] with appearance of collagen fibers $(\uparrow)$ running between and surrounding the hepatocytes [a\&b]. Note the congested branches of Portal vein (PV) and hepatic artery (HA) [b]. Group III, Masson's trichrome x 400
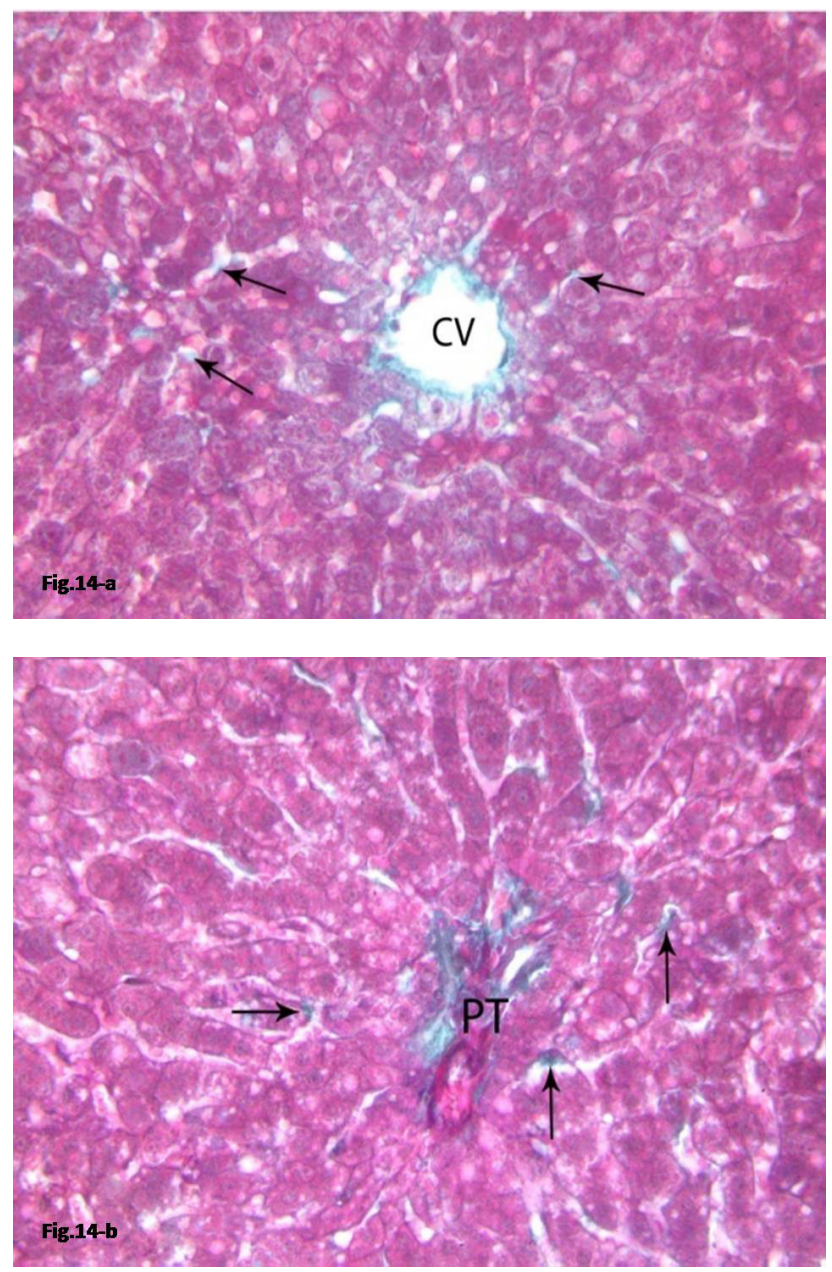

Fig. 14: $(a \& b)$. Minimal amount of collagen fibers are seen around the central vein $(\mathrm{CV})[\mathrm{a}]$, portal tract $(\mathrm{PT})[\mathrm{b}]$ and within perisinusoidal spaces $(\uparrow)$ [a\&b]. Group IV, Masson's trichrome x 400

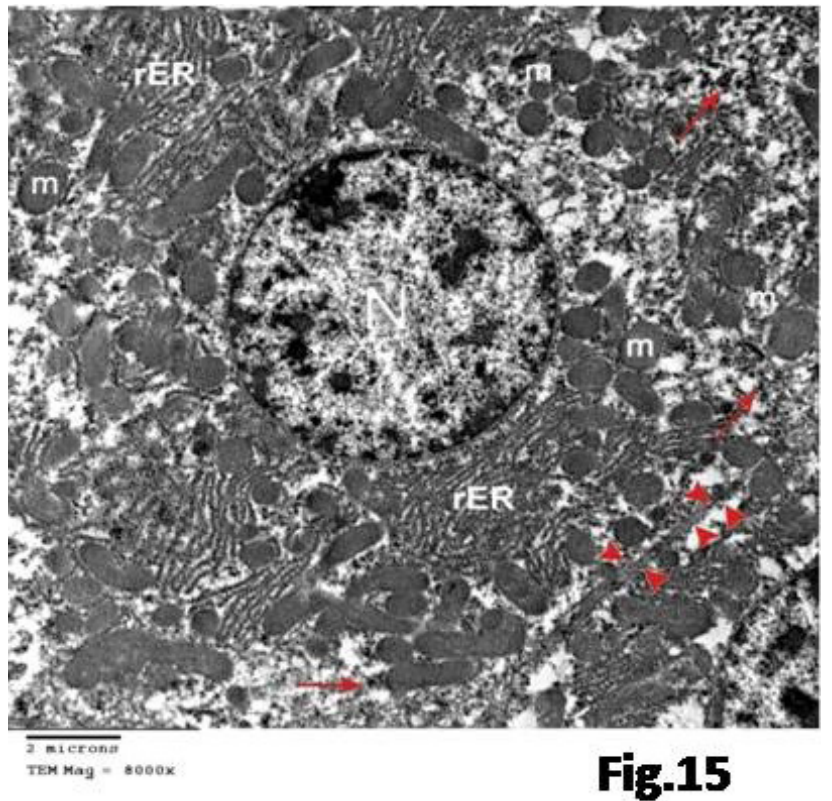

Fig. 15: An electron micrograph showing part of a hepatocyte containing euchromatic nucleus $(\mathrm{N})$. Mitochondria $(\mathrm{m})$ variable in shape with apparent cristae are seen in association with rough endoplasmic reticulum (rER). Rosettes of glycogen granules (red arrow $\uparrow$ ) scattered in cytoplasm are also conspicuous. The cell membrane between two adjacent hepatocytes is noticed (red arrow head $\mathbf{\Delta}$ ). Group I, TEM x 8000

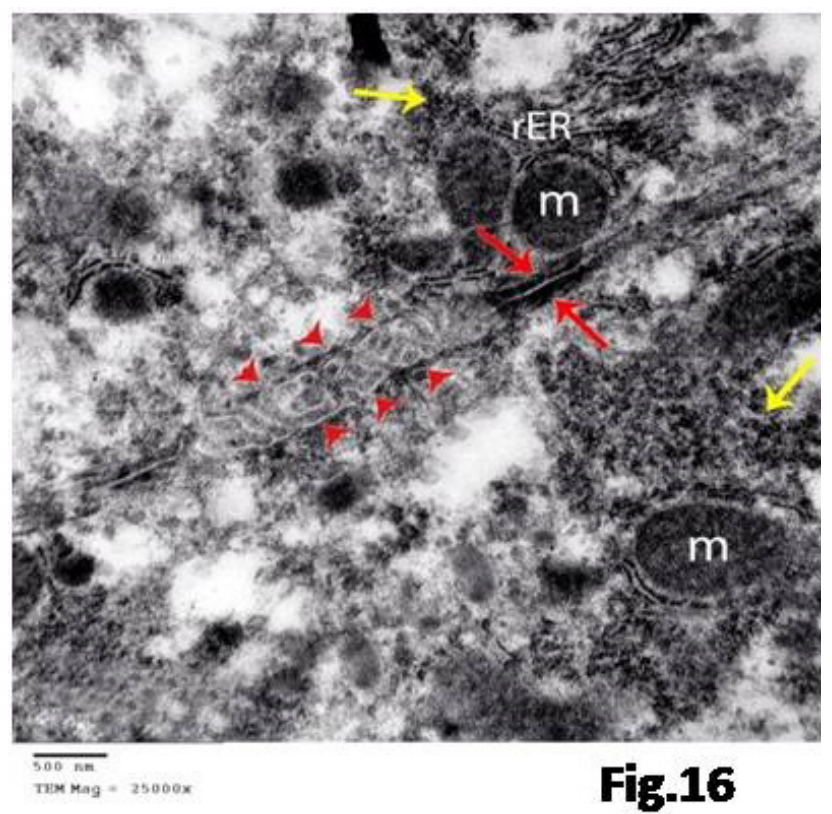

Fig. 16: An electron micrograph showing bile canaliculus in between adjacent hepatocytes (red arrow head $\boldsymbol{\Delta}$ ). with short microvilli from the hepatocytes surface projecting into its lumen. Junctional complexes (red arrow $\uparrow$ ) appeared attaching hepatocytes to each other close to the bile canaliculus. Notice the mitochondria $(\mathrm{m})$, rough endoplasmic reticulum (rER) and rosettes of glycogen granules (yellow arrow $\uparrow$ ) within the hepatocytes. Group I, TEM x 25000 


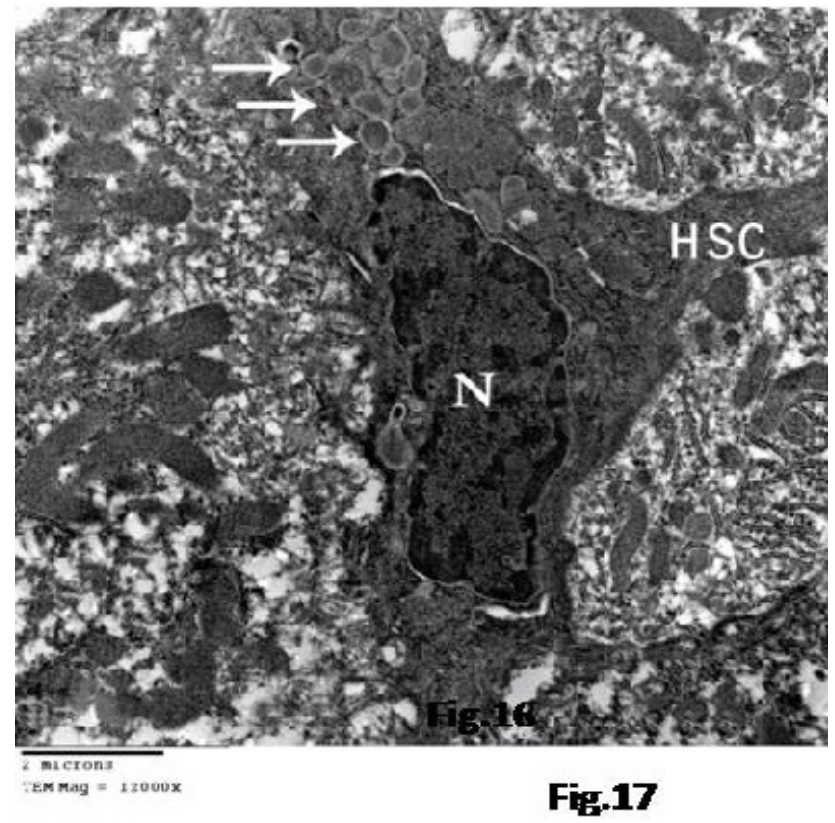

Fig. 17: An electron micrograph showing hepatic stellate cell (HSC) with elongated nucleus $(\mathrm{N})$ and multiple lipid droplets $(\uparrow)$ is seen within the cytoplasm Group I, TEM x 12000

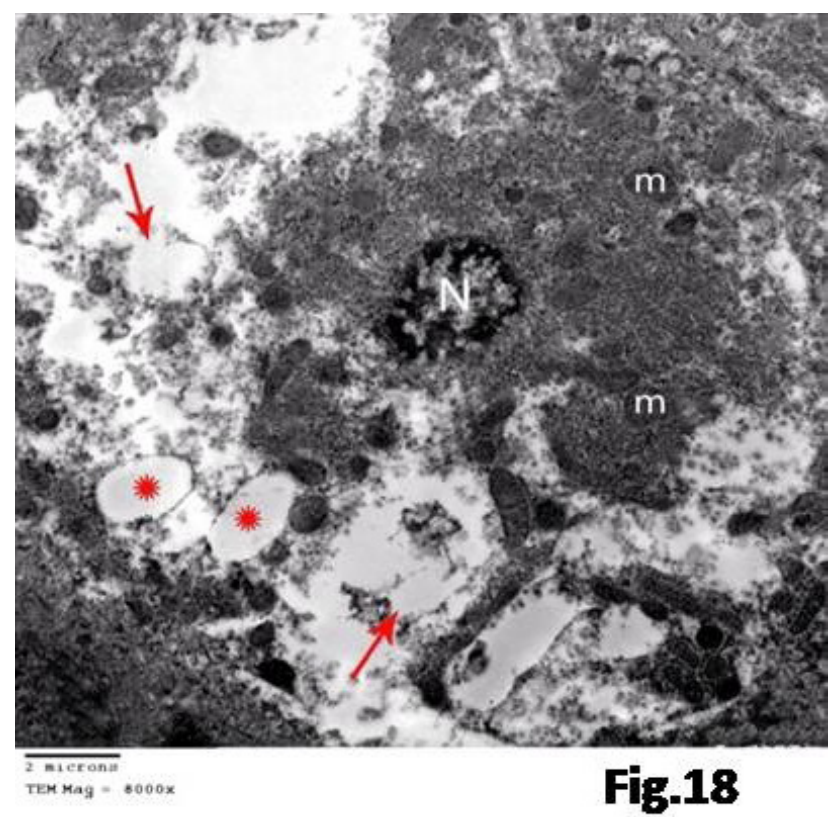

Fig. 18: An electron micrograph showing hepatocyte with vacuolated cytoplasm (red arrow $\uparrow$ ) and shrunken, irregular nucleus with more peripheral heterochromatin $(\mathrm{N})$. Small lipid droplets of variable size with well-defined edges are scattered in the cytoplasm (*). Apparent decrease in mitochondria $(\mathrm{m})$ and rough endoplasmic reticulum is noticed as compared to the control. Group III, TEM x 8000

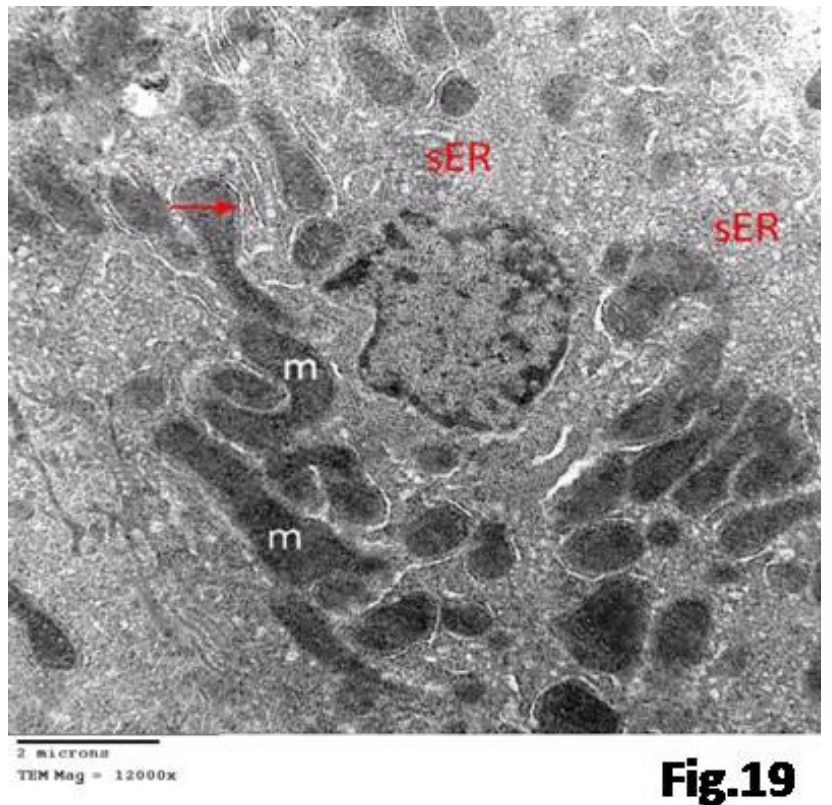

Fig. 19: An electron micrograph showing elongated distorted mitochondria (m) are evident in hepatocyte cytoplasm. Numerous profiles of smooth endoplasmic reticulum (sER) and few rER (red arrow $\uparrow$ ) are also noticed as compared the control group. Group III, TEM x 12000

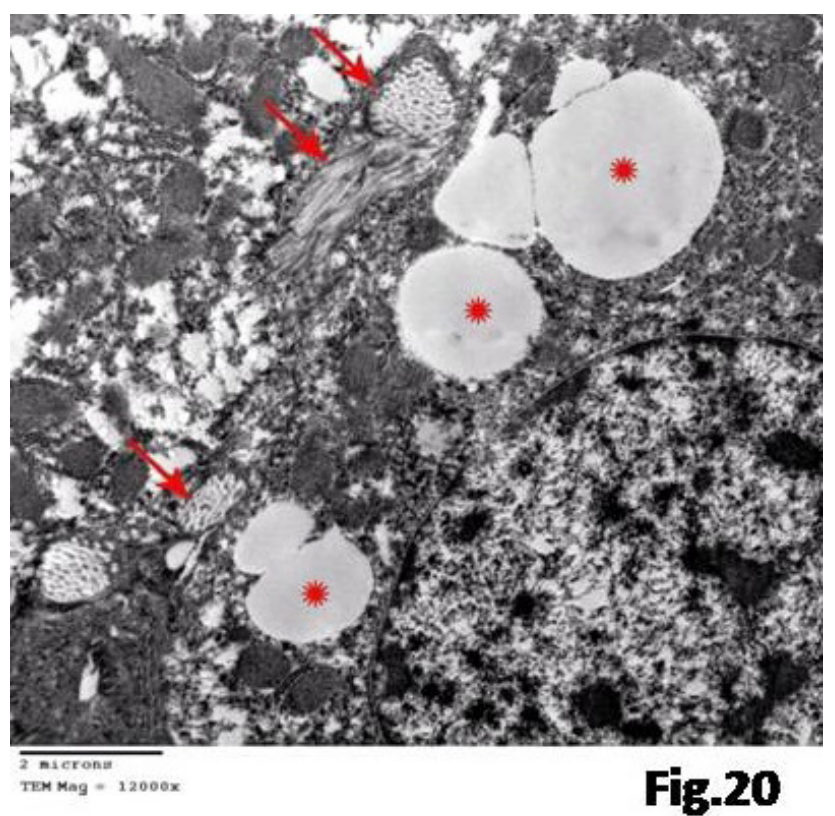

Fig. 20: An electron micrograph showing lipid droplets of variable size with well-defined edges scattered in the cytoplasm $(*)$. Notice the collagen fibrils (red arrow $\uparrow$ ) in between the hepatocytes. Group III, TEM x 12000 


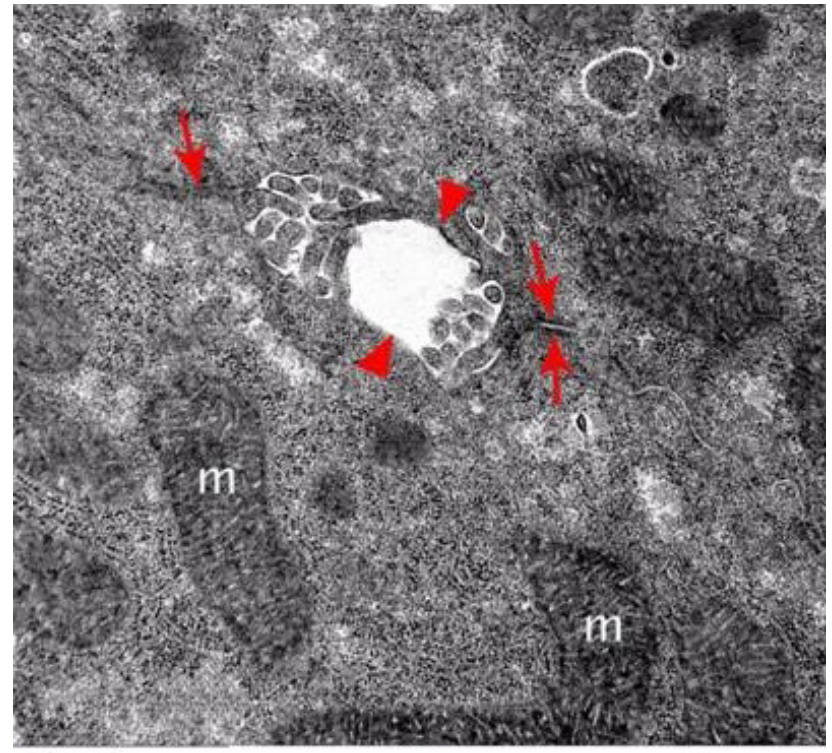

$\overline{500 \mathrm{~mm}}$

Tres Mag = 25000x

Fig.21

Fig. 21: An electron micrograph showing bile canaliculus with short microvilli projecting into its lumen and lacking in some sites when compared to that of the control group (red arrow head $\boldsymbol{\Delta}$ ). Junctional complexes are seen attaching hepatocytes to each other (red arrow $\uparrow$ ). Distorted elongated mitochondria are noticed (m). Group III, TEM x 25000

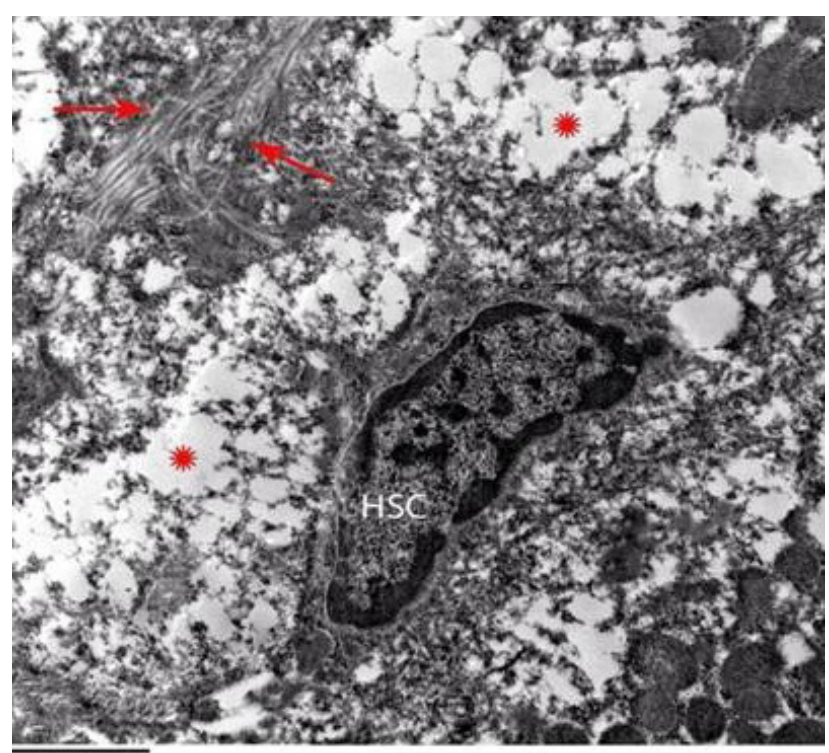

microna $=12000$ :

Fig-22

Fig. 22: An electron micrograph showing elongated Hepatic stellate cell (HSC) in between vacuolated hepatocytes $\left(^{*}\right)$ with cytoplasm nearly devoid of lipid droplets as compared to that of the control. Collagen fibrils are seen in between hepatocytes (red arrow $\uparrow$ ). Group III, TEM x 12000

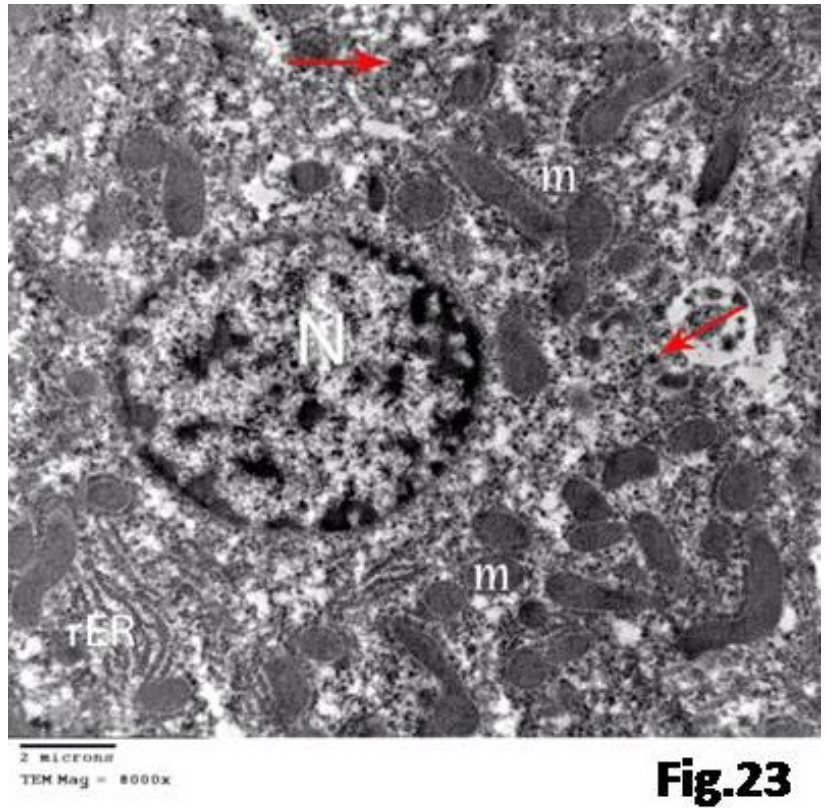

Fig. 23: An electron micrograph showing part of a hepatocyte containing euchromatic nucleus (N). Mitochondria (m), Rough endoplasmic reticulum (rER) and glycogen granules are also seen (red arrow $\uparrow$ ). Group IV, TEM x 8000

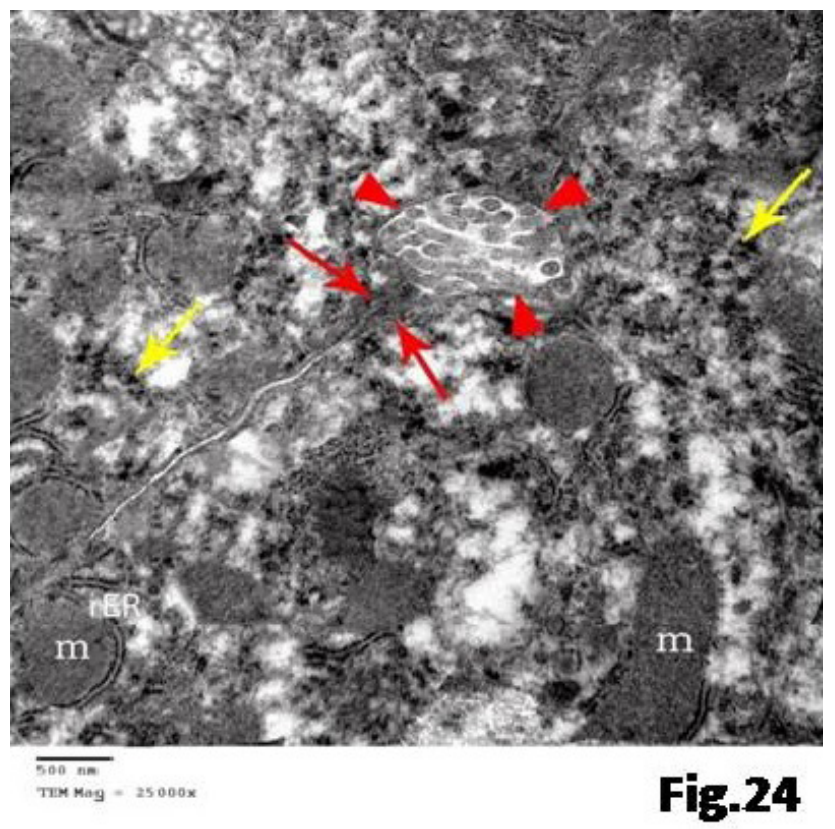

Fig. 24: An electron micrograph showing bile canaliculus with microvilli projecting into its lumen (red arrow head $\boldsymbol{\Delta}$ ). Cell membranes of the adjacent hepatocytes are attached to each other by junctional complexes close to the canaliculus (red arrow $\uparrow$ ). Mitochondria (m), rough endoplasmic reticulum (rER) and rosettes of glycogen (yellow arrow $\uparrow$ ) are seen. Group IV, TEM x 25000 


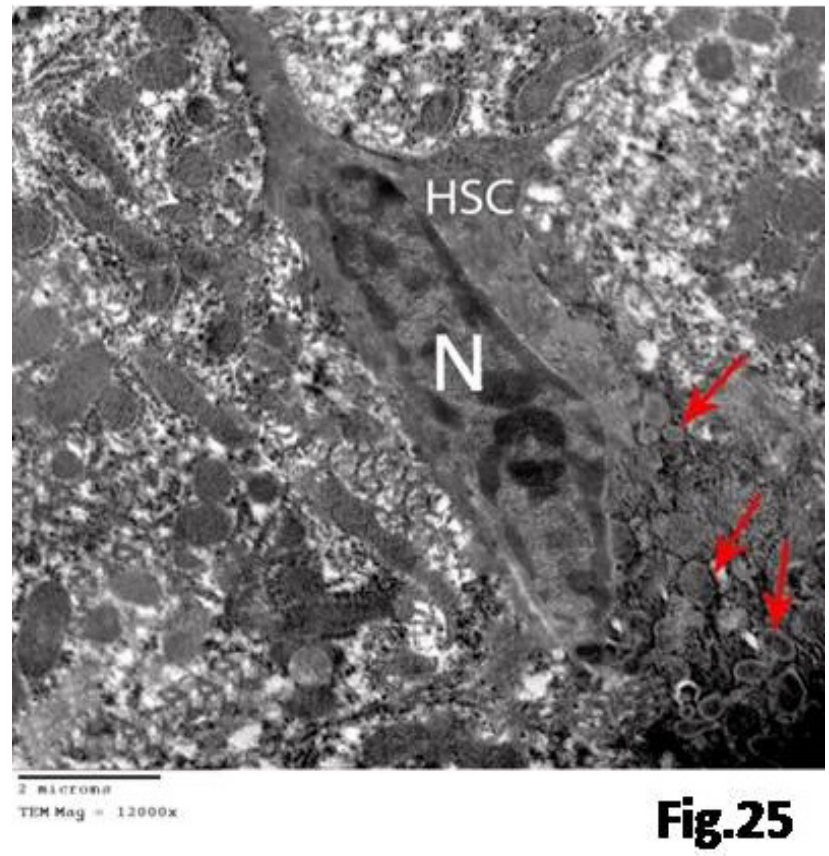

Fig. 25: An electron micrograph showing hepatic stellate cell (HSC) lying in between hepatocytes with elongated nucleus $(\mathrm{N})$ and multiple lipid droplets $(\uparrow)$ in its cytoplasm. Group IV, TEM x 12000
Table 1: Showing changes in Area percentage of glycogen granules represented by mean + standard deviation in different groups

\begin{tabular}{|c|c|c|c|c|}
\hline & Group I & Group II & Group III & Group IV \\
\hline $\begin{array}{c}\text { Area } \\
\text { percentage } \\
\text { of glycogen } \\
\text { granules }(\%)\end{array}$ & $\begin{array}{c}30.056+ \\
9.55398^{+}\end{array}$ & $\begin{array}{c}31.694+ \\
8.73946^{=0}\end{array}$ & $\begin{array}{c}8.012+ \\
5.34855^{* \star \Delta}\end{array}$ & $\begin{array}{c}25.918+ \\
7.77991^{-0}\end{array}$ \\
\hline $\begin{array}{l}\text { * Significant d } \\
\text { \& Significant d } \\
\text { - Significant d } \\
\text { ه Significant }\end{array}$ & $\begin{array}{l}\text { ference fron } \\
\text { ference frol } \\
\text { ference fror } \\
\text { fference fro }\end{array}$ & $\begin{array}{l}\text { roup I. } \\
\text { roup II. } \\
\text { group III. } \\
\text { group IV. }\end{array}$ & & \\
\hline
\end{tabular}

Table 2: Showing changes in area percentage of collagen fibers represented by mean + standard deviation in different groups

\begin{tabular}{|c|c|c|c|c|}
\hline & Group I & Group II & Group III & Group IV \\
\hline $\begin{array}{l}\text { Area } \\
\text { percentage } \\
\text { of glycogen } \\
\text { granules }(\%)\end{array}$ & $\begin{array}{c}13.33+ \\
2.33877\end{array}$ & $\begin{array}{c}13.019+ \\
2.21443^{ } \mathrm{O}\end{array}$ & $\begin{array}{c}18.162+ \\
5.80943^{* \star \Delta}\end{array}$ & $\begin{array}{c}14.281+ \\
3.43168^{=0}\end{array}$ \\
\hline \multicolumn{5}{|c|}{$\begin{array}{l}\text { * Significant difference from group I. } \\
\text { \& Significant difference from group II. } \\
\text { - Significant difference from group III. } \\
\text { A Significant difference from group IV. }\end{array}$} \\
\hline O Non- signifi & nt differen & from group I & & \\
\hline
\end{tabular}

Table 3: Showing changes in biochemical measurement (ALT, AST and ALP) represented by mean +standard deviation in different groups

\begin{tabular}{|c|c|c|c|c|}
\hline & Group I & Group II & Group III & Group IV \\
\hline $\operatorname{ALT}(\mathrm{IU} / \mathrm{L})$ & $28.4+8.127$ & $27.1+3.665^{\bullet 0}$ & $67.9+9.689 * 4$ & $28.9+9.871^{-0}$ \\
\hline AST (IU/L) & $23.2+9.199 "$ & $20.8+5.412^{-0}$ & $82.0+18.3^{* \star \Delta}$ & $24.0+8.014^{-0}$ \\
\hline ALP (IU/L) & $68.3+15.6^{=}$ & $65.6+14.976^{\bullet 0}$ & $263+91.308^{* \star \Delta}$ & $67.2+15.259=0$ \\
\hline
\end{tabular}

*Significant difference from group I.

Significant difference from group II.

- Significant difference from group III.

$\Delta$ Significant difference from group IV.

ONon-significant difference from group I.

Table 4: Showing changes in biochemical measurement of tissue MDA represented by mean + standard deviation in different groups

\begin{tabular}{lccc}
\hline & Group I & Group II & Group III \\
\hline \multicolumn{1}{c}{ Tissue MDA (umol/g) } & $4.629+1.2937^{\star}$ & $4.427+1.62077^{* 0}$ & $10.819+1.52343^{* \star \Delta}$ \\
\hline *Significant difference from group I. & $\boldsymbol{\Delta}$ Significant difference from group II. \\
-Significant difference from group III. & Significant difference from group IV. \\
ONon- significant difference from group I. & & $4.435+1.42364 * 0$
\end{tabular}

Table 5: Showing changes in biochemical measurement of Tissue GSHPx and catalase represented by mean + standard deviation in different groups

\begin{tabular}{|c|c|c|c|c|}
\hline & Group I & Group II & Group III & Group IV \\
\hline Tissue GSHPx (U/g) & $672.113+143.13622=$ & $816.667+392.02487^{* \boldsymbol{M}}$ & $191.193+51.87027^{* \star \Delta}$ & $656.447+149.0886^{-O}$ \\
\hline Tissue Catalase (umol/g) & $3.539+0.43778^{-}$ & $4.732+1.44193^{* \boldsymbol{~}}$ & $1.151+0.38339 * \Delta$ & $3.49+0.77236^{-\mathrm{O}}$ \\
\hline
\end{tabular}

*Significant difference from group I.

- Significant difference from group III.

O Non- significant difference from group I.
- Significant difference from group II.

A Significant difference from group IV. 


\section{DISCUSSION}

In this study, orally given aqueous extract of Moringa leaves was chosen; as it is easily prepared and readily administrated ${ }^{[20]}$ so, it can be easily prepared at home by any one. Moreover, toxicity studies have shown that it has no significant adverse effects in rats and rabbits ${ }^{[24]}$. In the present study, rats treated with Moringa oleifera Leaf extract (Group II) showed hepatic architecture nearly similar to that of the control. No hepatocyte injury was observed. This was also confirmed by the electron microscope examination, where the ultra structure of the liver tissue was comparable to that of the control. This was in consistence with some authors ${ }^{[25]}$ who reported that rats received Moringa oleifera alone showed normal cellular architecture by light microscopy with no remarkable changes in comparison with the control. Any marked necrosis of the liver cells leads to a significant rise of Liver transaminases in the blood and a substance that doesn't affect their level is considered non-toxic to the hepatocytes ${ }^{[26]}$. So the blood liver function tests in the current study were done and it was found that there was no significant difference between the control rats and the rats treated with Moringa oleifera leaf extract (Group II).

Rats received Moringa extract in the current study, showed significant increase in GSHPx and catalase activity and no significant difference of MDA level as compared to that of the control. This was in accordance with some investigators ${ }^{[27]}$. Other authors reported that treatment with Moringa oleifera or with phytochemicals isolated from Moringa oleifera have shown elevation of a variety of antioxidant enzymes ${ }^{[28]}$. It was found that tocopherols, phenolics and carotenoids are natural antioxidant components found in Moringa oleifera. ${ }^{[25]}$

The light microscopic examination of liver sections of rats treated by paracetamol (Group III), in the current study, showed that most of the hepatocytes appeared swollen with vacuolated cytoplasm and shrunken, irregular and darkly stained nuclei. This was supported by electron microscopic results which revealed the presence of vacuoles and fat droplets in the hepatocytes. Moreover, mitochondria was apparently decreased as compared to the control, and appeared elongated and distorted in some hepatocytes. Few rough endoplasmic reticulum with abundant smooth endoplasmic reticulum was also noticed. These morphological changes were similar to those described by some authors ${ }^{[29 \& 30]}$ who revealed that paracetamol induced degeneration of the mitochondria and some of them were described as mega mitochondria. There were also endoplasmic reticulum distension, hyperplasia and breakdown. Moreover, other researchers ${ }^{[31]}$ outlined that exposure to paracetamol resulted in endoplasmic reticulum (ER) fragmentation, vacuolization and decrease in membrane bound ribosomal particles. Paracetamol, a potentially toxic stimulus, induces disturbance in phospholipid metabolism which in turn leads to appearance of lipid droplets ${ }^{[32]}$. Also, paracetamol caused oxidative stress and created reactive oxygen species (ROS) within the mitochondria. This leads to mitochondrial DNA damage, opening of the mitochondrial permeability transition pore, and cessation of ATP production ${ }^{[33]}$. Moreover, paracetamol induces disruption of calcium homeostasis which results in activation of many membrane damaging enzymes (like ATPases, phospholipases, proteases and endonucleases), disruption of mitochondrial metabolism and ATP synthesis and damage of microfilaments used to support cell structure ${ }^{[1]}$. Also, in this study microvilli projecting into the lumen of the bile canaliculi were apparently shorter and lacking in some sites when compared to that of the control group. This was in accordance with other researchers $^{[34]}$ who described a dilation of bile canaliculi and loss of microvilli in liver sections of mice pretreated with paracetamol. This finding may be attributed to the loss of outer membrane integrity of hepatocytes ${ }^{[35]}$. Cellular infiltration and congestion in central and portal veins were also observed in the current work. The appearance of congestion was described by other investigators ${ }^{[36]}$. The appearance of congestion was attributed to the induction of morphologic changes and to alterations in the relationship between hepatocytes and sinusoidal lining cells as a result of paracetamol toxicity ${ }^{[34]}$. Cellular infiltrations (lymphocytes and neutrophils) were also reported in another work ${ }^{[26]}$. Infiltration of inflammatory cells into perivascular spaces and portal triad was observed in paracetamol treated rats ${ }^{[37]}$. Mitochondrial damage causes activation of Kupffer cells which in turn release cytokines and chemokines that recruit neutrophils and monocytes and cause cellular injury. The direct action of cytokines and chemokines, rather than inflammatory cells, is thought to cause cellular injury by altering intracellular events within hepatocytes ${ }^{[38]}$. Paracetamol administration leads to an increase in the proinflammatory cytokines; as tumor necrosis factor (TNF)- $\alpha$ or interleukin (IL)-1 $\beta^{[39]}$

An apparent increase in the number of the lining cells of bile ductules was also noticed in paracetamol treated group of this study. This was reported in a previous work ${ }^{[37]}$. It was hypothesized that when liver is exposed to injurious stimulus, cholangiocytes hyperplasia may occur. Three types of cholangiocytes proliferation were suggested; Type I "Typical", Type II "Atypical" and Type III "Oval cell". In type I, proliferation arises from older ducts, confined to portal areas and functional characteristics of cholangiocytes are preserved. Proliferating cholangiocytes exhibit stem cell markers. This type of proliferation can be associated with sprout of new side branches. This theory could be the case in our study which still needs further investigation. On the other hand, type II which is more common with chronic injury, results from retro-differentiation (transdifferentiation) of hepatocytes into cholangiocytes. Proliferating cholangiocytes are characterized by being not confined to portal areas, irregular, with no lumen and exhibit functional and cellular properties of both hepatocytes and cholangiocytes. While, Type III results from proliferation of non parenchymal germ cells (Oval cells) giving disorganized ducts that are randomly spread into hepatic lobules leading to distorted hepatic 
architecture. Oval cells can differentiate into hepatocytes, cholangiocytes and exocrine portion of pancreatic cells ${ }^{[40]}$.

In the present study, the paracetamol treated group also showed an apparent decrease in the PAS positive glycogen granules compared to that of the control, which was confirmed by the morphometric analysis. This was supported by preceding studies that agreed with these consequences $^{[41]}$. Also, significant increase in collagen fibers around the central vein, portal area and inbetween hepatocytes were observed in group III of this study as compared to the control. Additionally, this result was demonstrated by the electron microscopic examination which showed collagen fibrils in between the hepatocytes. Moreover, HSCs in association with collagen fibrils were frequently seen in between hepatocytes and they appeared elongated with no fat droplets in their cytoplasm. This was in accordance with some authors ${ }^{[42]}$ who, described that the presence of some fibrosis was consequent with ballooning degeneration, and that fibrosis is classically found encircling hepatocytes, so called peri-cellular fibrosis. Following liver injury, HSCs undergo activation ${ }^{[43]}$. Activated HSCs evolves into myofibroblast-like cells without lipid droplets and synthesize a large amount of extracellular matrix components including collagen, proteoglycan and adhesive glycoproteins ${ }^{[29]}$. Additionally, activated HSCs also synthesize tissue inhibitor of interstitial collagenases. So prevent collagen degradation leading to increase extracellular matrix ${ }^{[44]}$. HSCs activation was attributed to the release of cytokines and growth factors as a result of Kupffer cells activation by hepatocytes damage ${ }^{[45]}$. While, others accredited HSCs activation to oxidative stress ${ }^{[46]}$.

Histopathological findings in this study were verified by the biochemical analysis. The liver function tests showed significant increase in ALT, AST and ALP in paracetamol treated rats as compared to that of the control, similarly as reported by another researchers ${ }^{[47]}$. The transport function and membrane permeability are impaired by hepatocyte injury as a result of paracetamol toxicity, leading to leakage of enzymes from these cells. In addition, Paracetamol could be achieving its toxic effects by triggering oxidative stress $^{[48]}$. In the present study it was found that tissue MDA was significantly increased and tissue GSHPx and Catalase were significantly decreased as compared to the control in paracetamol group. This was in consistence with the results of some researchers ${ }^{[47]}$. They clarified that paracetamol leads to increased generation of reactive oxygen species (ROS). They added that the high level of ROS is known to cause impairment of antioxidant enzyme activities resulting in oxidative stress. Oxidative stress in turn induces various actions including lipid peroxidation, which is characterized by oxidative degeneration of membrane phospholipids. Malondialdehyde (MDA) level reflects the degree of lipid peroxidation in tissues especially hepatocytes ${ }^{[47 \& 48]}$ and elevated MDA product coincides with hepatotoxicity seen with administration of paracetamol ${ }^{[49]}$. The paracetamol induced liver injury was further explained by another authors ${ }^{[50]}$. Their theory denoted that cytochrome P4502E (CYP2E1) is the major catalyst involved in the metabolism of drugs, and Paracetamol is mainly metabolized by CYP2E1 to form an electrophilic metabolite, $\mathrm{N}$-acetyl-p-benzoquinone imine(NAPQI), which is primarily inactivated by conjugation with glutathione(GSH) and binding with other proteins to form protein adducts. Accumulation of the intermediate metabolites and the depletion of GSH are key mechanisms of paracetamol hepatotoxicity that directly cause liver damage. Hepatocytes containing adducts are undergoing necrotic changes as evidenced by vacuolization and pyknotic changes in the nuclei. In addition, the only hepatocytes observed to develop necrosis were those containing paracetamol protein adducts ${ }^{[51]}$. Moreover, paracetamol induced CYP2E1 expression, which increases NAPQI formation associated with paracetamol hepatotoxicity ${ }^{[47]}$.

In the current study, pre-administration of Moringa leaf extract prior to paracetamol in group IV led to amelioration of the toxic effect of paracetamol on the liver. The hepatocytes appeared less vacuolated and with vesicular nuclei compared to that of the paracetamol treated group (Group III). Minimal cellular infiltration around portal area was observed. Periodic Acid Schiff and Masson's trichrome stained sections showed nearly similar findings as compared to that of the control. These findings were confirmed by the morphometric analysis and the electron microscope examination as hepatocytes and bile canaliculi ultra structure appeared nearly similar to that of the control. No collagen fibrils were observed associated with HSCs which appeared with lipid droplets in their cytoplasm. These findings were in consistence with that of some authors ${ }^{[52]}$. They outlined that Moringa oleifera extracts protected the liver against paracetamol induced hepatic toxicity.

Also in this study, group IV showed an apparent increase in the number of cells lining bile ductules in the portal area and nearby bile canaliculi. This finding was in consistence with another investigators ${ }^{[36]}$ who reported mild proliferation of bile ducts in liver sections from rats treated by paracetamol preceded by Moringa oleifera. It was suggested that these proliferating cells might be proliferating cholangiocytes exhibiting stem cell markers (Type I "typical cholangiocytes proliferation"). Cholangiocytes might proliferate in an attempt to recover after exposure to injurious stimulus ${ }^{[40]}$.

It was suggested that the Moringa leaf extract afforded the hepatoprotection through decreased production of free radicals and by its membrane stabilizing activity ${ }^{[36]}$. This effect could be explained, at least in part, by the active ingredients present in the extracts ${ }^{[53]}$. High amount of B-carotene was reported in Moringa oleifera extracts ${ }^{[54]}$. Moreover, Moringa extract contains all essential amino $\operatorname{acids}^{[55]}$. It was hypothesized that the B-carotene of Moringa oleiferais responsible for the hepatoprotective activity ${ }^{[53]}$. B-carotene may exhibit a good radical trapping antioxidant $\operatorname{activity}^{[56]}$. Besides carotene, Moringa oleifera has been also reported to contain antioxidants such as vitamin $\mathrm{C}^{[57]}$. 
In addition, vitamin $\mathrm{C}$ present in Moringa oleifera might be responsible for the antioxidant activity ${ }^{[58]}$. Moringa leaf extracts were capable of scavenging peroxyl and superoxyl radicals. The major bio-active compounds of phenolics isolated from Moringa leaf extract were flavonoid groups such as quercetin and kaempferol and concluded that Moringaleaves are potential source of natural antioxidants due to their marked antioxidant activity ${ }^{[57]}$.

In the current study, blood liver function tests in rats pretreated with Moringa oleifera leaf extract (Group IV) showed that enzyme levels were nearly similar to the control group. Similar findings were observed in a previous work $^{[22]}$. The reversal of elevated serum intracellular enzyme levels by Moringa oleifera extract may be attributed to the stabilizing ability of the cell membrane preventing enzymes leakages ${ }^{[59]}$. Moreover, restoration of MDA level, GSHPx activity and catalase activity as compared to that of the paracetamol treated rats of group III was also noticed in this study. These results goes in parallel with another researchers ${ }^{[36]}$ who outlined that pre-treatment by Moringa Oleifera extracts in paracetamol treated rats reversed the reduction of GHSPx and catalase activity and the elevation in MDA. The role of the plant extract against paracetamol mediated hepatotoxicty could be explained by the ability of the plant to prevent GSHPx and catalase activity impairment. It has effectively scavenged the occurrence of free radicals generated during paracetamol metabolism and subsequently reduced the destructive effects of oxidative stress. Apart from this, phytochemical analysis has revealed the presence of natural antioxidants in Moringa extracts such as phenolics compounds including flavonoid groups such as quercetin and kaempferol ${ }^{[60]}$. Induction of hepatotoxicity by ROS can be prevented following the administration of an agent with antioxidant capacity ${ }^{[61]}$. Moringa oleifera remarkably modulated the oxidative stress due to its free radicals scavenging capability ${ }^{[62]}$.

Consequently, it was concluded that Moringa oleifera extracts could protect the structure and function of the liver against the effects of paracetamol. This hepatoprotective effect is due to inhibition of lipid peroxidation and enhancementof antioxidant enzymes.

\section{CONFLICTS OF INTEREST}

There are no conflicts of interest

\section{REFERENCES}

1. Singh A, Bhat TK, Sharma OP. Clinical Biochemistry of Hepatotoxicity. Journal of Clinical Toxicology 4, article 2011; 001: 1-19.

2. Friedman SE, Grendel JH andMcQuaid, KR. Current diagnosis \& treatment in gastroenterology. $2^{\text {nd }}$ edition. New York: Lang Medical Books/ McGraw-Hill 2003;664-679.

3. Huang $\mathrm{B}$, Ban $\mathrm{X}$, He J, Tong J, Tian J, Wang Y. Hepatoprotective and antioxidant activity of ethanolic extracts of edible lotus
(NelumbonuciferaGaertn.) leaves. Food Chem 2010; 120: 873-878.

4. Yousef MI, Omar SA, El-Guendi MI, Abdelmegid LA. Potential protective effects of quercetin and curcumin on paracetamol-induced histological changes, oxidative stress, impaired liver and kidney functions and haematotoxicity in rat. Food ChemToxicol 2010; 48: 3246-3261.

5. Mahmood KT, Mugal T, Haq IU. Moringa oleifera: A natural gift- A review. J Phar Sci 2010; 2: $775-781$

6. Mughal MHS, Ali G, Srivastava PS, Iqbal M. Improvement of drumstick (Moringa pterygospermaGaertn.) A unique source of food and medicine through tissue culture. Hamdard Med 1999; 42: 37-42.

7. Somali MA, Bajnedi, MA, Al-Faimani SS Chemical composition and characteristics of Moringa peregrina seeds and seed oil. J Am Oil Chem Soc1984; 61: 85-86.

8. Thurber MD and Fahey JW. Adoption of Moringa oleifera to combat under-nutrition viewed through the lens of the "diffusion of innovations" theory. Ecol Food Nutr 2009; 48: 212-225.

9. Von MHJ. Trees and Shrubs of Sahel, Their Characterization and Uses. Deutsche Gesellschaft fur Techni sche Zusammenarbeit 1986; 334-337.

10. Torimiro DO, Odeyinka SM, Okorie VO, Akinsuyi MA. Gender analysis of socio-cultural perception of Moringa oeifera amongst farmers in southwestern Nigeria. J Int Womens Stud 2009; 10: 188-202.

11. Paliwal R, Sharma V, Pracheta SS. A review of Horse Radish Tree (Moringa oleifera): A Multipurpose Tree with High Economic and Commercial Importance. Asian Journal of Biotechnology 2011; 3 (4): 317-328.

12. Amaglo NK, Bennett RN, Lo Curto RB, Rosa EAS, Lo Turco V, Giuffrid A, Lo Curto A, Crea F, Timpo GM. Profiling selected phytochemicals and nutrients in different tissues of the multipurpose tree Moringa oleifera L., grown in Ghana. Food Chem 2010; 122: 1047-1054.

13. Hinson JA. Biochemical toxicology of acetaminophen. Rev Biochem Toxicol 1980; 2:103-129.

14. Ostapowicz G, Fontana RJ, Schiodt FV, Larson A, Davern TJ, Han SH, McCashland TM, Shakil AO, Hay JE, Hynan L, Crippin, JS, Blei AT, Samuel G, Reisch J, Lee WM. Results of a prospective study of acute liver failure at 17 tertiary care 
centers in the United States. Ann Intern Med 2002; 137:947-954.

15. Litovitz TL, Klein-Schwartz W, Rodgers GCJr, Cobaugh DJ, Youniss J, Omslaer JC, May ME, Woolf AD, Benson BE. 2001 Annual report of the American Association of Poison Control Centers Toxic Exposure Surveillance System. Am J Emerg Med 2002; 20: 391-452.

16. Larson AM, Polson J, Fontana RJ, Davern TJ, Lalani E, Hynan LS, Reisch JS, Schiødt FV, Ostapowicz G, Shakil AO, Lee WM. Acetaminophen-induced acute liver failure: results of a United States multicenter, prospective study. Hepatology 2005; 42: 1364-1372.

17. Wallace JL. Acetaminophen hepatotoxicity: NO to the rescue. Br J Pharmacol 2004; 143: 1-2.

18. Sreelatha S and Padma PR. Antioxidant activity and total phenolic content of Moringa oleifera leaves at two stages of maturity. Plant Foods Hum Nutr 2009; 64: 303-311.

19. Verma VK, Singh N, Saxena P, Singh R. Antiulcer and antioxidant activity of Moringa oleifera (lam) leaves against aspirin and ethanol induced gastric ulcer in rats.Int. Res $\mathrm{J}$ of Pharmaceuticals 2012; 2 (2): 46-57.

20. Berkovich L, Earon G, Ron, I, Rimmon A, Vexler A, Lev-Ari S. Moringa Oleifera aqueous leaf extract down regulates nuclear factor-kappaB and increases cytotoxic effect of chemotherapy in pancreatic cancer cells.BMC Complementary and Alternative Medicine 2013; 13: 212- 219.

21. Kanchana N And Sadiq AM. Hepatopotective effect of Plumbago Zeylanica on Paracetamol induced liver toxicity in rats. International Journal of Pharmacy and Pharmaceutical Sciences 2011; 3 (1), 151-154.

22. Fakurazi S, Sharifudin SA, Arulselvan P. Moringa oleifera Hydroethanolic Extracts Effectively Alleviate Acetaminophen-Induced Hepatotoxicity in Experimental Rats through Their Antioxidant Nature Molecules. 2012; 17: 8334-8350.

23. Esterbauer H and Cheeseman KH. Determination of aldehydic lipid peroxidation products: malonaldehyde and 4-hydroxynoneal. Methods in Enzymology.1990; 186: 407-421.

24. Isitua $\mathrm{CC}$ and Ibeh IN. Toxicological assessment of aqueous extract of Moringa oleifera and Caulis bambusae leaves in rabbits. Journal of Clinical Toxicology, supplement 2013; 12, article 003:1-4.

25. Ezejindu DN, Udemezue OO, Chinweife KC. Hepatoprtective effects of Moringa oleifera extract on liver of wistar rats. Journal of Research In Medical and Health Sciences 2014; 3 (5): 23-27.
26. Senthilkumar R, Chandran R, Parimelazhagan T. Hepatoprotective effect of Rhodiolaimbricate rhizome against paracetamol-induced liver toxicity in rats. Saudi Journal of Biological Sciences 2014; 21: $409-416$.

27. Kumar NA and Pari L. Antioxidant action of Moringa oleifera lam. (drumstick) against antitubercula rdrugs induced lipid peroxidation in rats. J Med Food 2003; 6: 255-259.

28. Saalu LC, Osinubi AA, Akinbami AA, Yama OE, Oyewopo AO, Enaibe BU. Moringa oleiferaLamarck (drumstick) Leaf Extract Modulates the Evidences of Hydroxyurea Induced Testicular Derangement International Journal of Applied Research in Natural Products 2011; 4 (2): 32-45.

29. Chang W, Song L., Yi T, Shen K, Wang H, Gao, X, Li M, Xu J, Niu W, Qin X. Early activated hepatic stellate cell-derived moleculesreverse acute hepatic injury. World J Gastroenterol 2015; 21(14): 4184-4194.

30. Zhang J, Song S, Pang Q, Zhang R, Wan Y, Yuan $\mathrm{D}, \mathrm{Wu} \mathrm{Q}$, Liu C. Hydrogen-rich water protects against acetaminopheninducedhepatotoxicity in mice. World J Gastroenterol 2015; 21(14): 41954209.

31. Kalinec GM, Thein P, Parsa A, Yorgason J, Luxford W, Urrutia R, Kalinec F. Acetaminophen and NAPQI are Toxic to Auditory Cells via Oxidative and Endoplasmic Reticulum Stress-dependent Pathways. Hear Res 2014; 313: 26-37.

32. Balajiraghavendran $H$, Sathivel A, Devaki $T$. Defensive nature of Sargassumpolycystum (Brown alga)against acetaminophen-induced toxic hepatitis in rats: Role of drug metabolizing microsomal enzyme system, tumor necrosis factor- $\alpha$ and fate of liver cell structural integrity. China World J Gastroenterol 2006; 12(24): 38293834.

33. Lee KK, Imaizumi N, Chamberland SR, Alder NN, Boelsterli UA. Targeting mitochondria with methylene blue protects mice against acetaminophen-induced liver injury. Hepatology 2015; 61 (1): 326-336.

34. Walker RM, Racz WJ, Mcelligoit TF. Scanning Electron Microscopic Examination of Acetaminophen-Induced Hepatotoxicity and Congestion in Mice. AJP 1983; 113 (3): 321-330.

35. Farber JL and Gerson RJ. Mechanisms of cell injury with hepatotoxic chemicals. Pharmacol. Rev 1984.; 36:71S-75S.

36. Babu BP, Ravi Kumar P, Bharavi K, Venkateswarlu U, Devi VR, Srilatha C. Protective Effect of 
Moringa oliefera Lam Leaf Extract in Paracetamol Induced Hepatotoxic Rat Model. IJPI's Journal of Pharmacology and Toxicology 2011; 1: 25-34.

37. Simeonova R, Vitcheva V, Kondeva-Burdina M, Krasteva I, Manov V, Mitcheva M. Hepatoprotective and antioxidant effects of Saponarin, isolated from Gypsophila Trichotoma Wend. on Paracetamol-induced liver damage in rats. Bio Med Research International 2013; 1:10.

38. Jaeschke H, Williams CD, Ramachandran A, Bajt ML. Acetaminophen hepatotoxicity and repair: the role of sterile inflammation and innate immunity. Liver Int 2012; 32: 8-20.

39. Blazka ME, Wilmer JL, Holladay SD, Wilson RE, Luster MI. Role of proinflammatory cytokines in acetaminophen hepatotoxicity. Toxicol Appl Pharmacol 1995; 133: 43-52.

40. Ray D, Han Y, Maroni L, Marzio M, Meng F, ALpini G, Glaser S. Liver Regeneration: Basic Mechanisms, Relevant Models and Clinical Applications. Academic press; ed. Apte, U.M 2015; 229- 241.

41. Iverson SV, Eriksson S, Xu, J, Prigge JR, Talago EA, Meade TA, Meade ES, Capecchi MR, Arnér ESJ, Schmidt EE. A Txnrd1-dependent metabolic switch alters hepatic lipogenesis, glycogen storage, and detoxification. Free Radical Biology and Medicine 2013; 63: 369-380.

42. David AL, Robin R, Alastair DB, David JH, Stewart F. Muir's text book of pathology. Fourteenth edition. Great Britain: Edward Arnold 2008; 268 .

43. Friedman SL. Hepatic stellate cells: protean, multifunctional, and enigmatic cells of the liver. Physiol Rev 2008; 88: 125-172.

44. Burt AD. Cellular and molecular aspects of hepatic fibrosis. J Pathol 1993.; 170:105-114.

45. Bauer $M$ and Schuppan D. TGFbetal in liver fibrosis: time to change paradigms? FEBS Lett 2001;502:1-3.

46. Yang FR, Fang BW, Lou JS. Effects of HaobieYangyinRuanjian decoction on hepatic fibrosis induced by carbon tetrachloride in rats. World J Gastroenterol 2010;16:1458-1464.

47. Parvin Mazraati and Mohsen Minaiyan. Hepatoprotective effect of Metadoxine on Acetaminophen-induced Liver Toxicity in Mice. Adv Biomed Res. 2018; 7:67

48. Azim SA, Abdelrahem M T, Said MM, khattab A. Protective effect of moringa peregrina leaves extract on acetaminophen -induced liver toxicity in albino rats. Afr J Tradit Complement Altern Med
2017; 14 (2): 206-216.

49. Uma N, Fakurazi S, Hairuszah I. Moringa oleifera Enhances Liver Antioxidant Status via Elevation of Antioxidant Enzymes Activity and Counteracts Paracetamol-induced Hepatotoxicity. Mal J Nutr 2010; 16(2): 293 - 307.

50. Kon K, Kim JS, Jaeschke H, Lemasters JJ. Mitochondrialpermeability transition in acetaminophen-induced necrosis andapoptosis of cultured mouse hepatocytes. Hepatology 2004; 40: 1170-1179.

51. Hinson JA, Roberts DW, James, LP. Mechanisms of acetaminophen-induced liver necrosis. Handb Exp Pharmacol 2010; 196: 369-405.

52. Olatosin TM, Akinduko DS, Uche CZ, Bardi J. Effects of Moringa oleifera Seed Oil on Acetaminophen-Induced Oxidative Stress and Liver Damage in Wistar Albino Rats. IOSR Journal of Pharmacy and Biological Sciences 2014; 9(2): 53-59.

53. Pari L and Kumar NA. Hepatoprotective Activity of Moringa oleifera on Antitubercular Druginduced Liver Damage in Rats. J Med Food 2002; 5: 169-175.

54. 54. Makkar HPS and Becker K. Nutritional value and antinutritional components of whole and ethanol extracted Moringa oleifera leaves. Anim Feed Sci Technol 1996; 63: 211- 228.

55. Nambiar VS and Seshadri S. b-Carotene content of some green leafy vegetables of Western India by HPLC. J Food Sci Technol 1998; 35: 365-367.

56. Bast A, Van-der-plas RM, Van-den-Berg H, Haenen GR (1996): Beta carotene as antioxidant. Eur J ClinNutr; 53: S54-S56.

57. Siddhuraju P and Becker K Antoxidant properties of various solvent extracts of total phenolic of constituents from three different agroclimatic origins of drumstick tree (Moringa oleifera tree lam) leaves. J. Agric Food Chem 2003; 51:21442155 .

58. Rao VA, Devi PU, Kamath R. In vivo radioprotective effect of Moringa oleifera leaves. Indian J Exp Biol 2001; 39: 858-863.

59. Saalu LC, Ogunlade B, Ajayi GO, Oyewopo AO, Akunna GG, Ogunmodede OS. The hepatoprotective potentials of Moringa oleifera leaf extract on alcohol-induced hepato-toxicity in wistar rat. Am. J. Bio technol. Mol. Sci 2012; 2 (1): 6-14.

60. Saalu LC, Osinubi AA, Akinbami AA, Yama OE, Oyewopo AO, Enaibe BU. Moringa oleiferaLamarck (drumstick) Leaf Extract 
Modulates the Evidences of Hydroxyurea Induced Testicular Derangement International Journal of Applied Research in Natural Products 2011; 4 (2): 32-45.

61. Attri S, Rana SV, Vaiphei K, Sodhi CP, Katyal R, Goel RC, Nain CK, Singh K. Isoniazid- and rifampicin-induced oxidative hepatic injury- protection by $\mathrm{N}$-acetylcysteine. Hum Exp Toxicol 2000; 19(9): 517-522.

62. Sharifudin SA, Fakurazi S, Hidayat MT, IthninHairuszah I, Moklas MAM, Arulselvan P. Therapeutic potential of Moringa oleifera extracts against acetaminophen-induced hepatotoxicity in rats. Pharmaceutical Biology 2013; 51(3): 279-288. 
الملخص العربى

\title{
دراسة هستولوجية عن الاور الوقائي المحتمل لمستخلص أوراق المورينجا

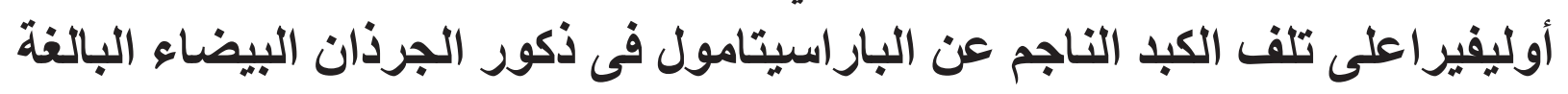

\author{
دينا م. المرسي، نجلاء م .أبو رابية، جيهان خلف، سمر ف. عزت \\ قسم الهستولوجيا وبيولوجيا الخليةـ كلية الطب- جامعة عين شمس مبرس
}

المورينجا أوليفيرا هي شجرة استو ائية عرفت اور اقها بكونها غنية بالمو اد المضادة للأكسدة ـ يعدالتسمم الكبدي الناتج عن البار اسيتامول من المحاذير الهامه للصحة العامة . الهـف من هذا البحث: هو دراسة الدور الوقائي المحتمل للمستخلص المائي لأوراق المورينجا اوليفير ا فى اصابة الكبد الناجمة عن البار اسيتامول في الجرذان البيضاء البالغة. المواد والطرق: تم استخدام أربعين ذكر ا من الجرذان البيضاء البالغة في الدراسة الحالية. وتم تقسيمهم إلى أربع مجموعات متساوية المجموعة الأولى : (المجموعة الضابطة) المجموعة الثانية : تم إعطائها مستخلص أوراق المورينجا اوليفير ا المائي لمدة14 يوما ـ المجمو عة الثالثة :تم إعطائها ماء لمدة 7 أيام بداية من اليوم السابع ثم إعطائها

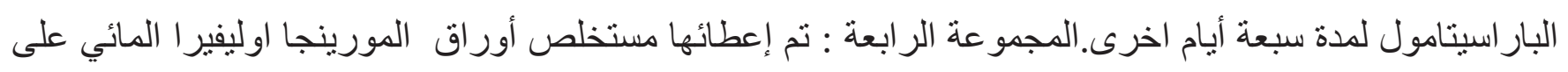

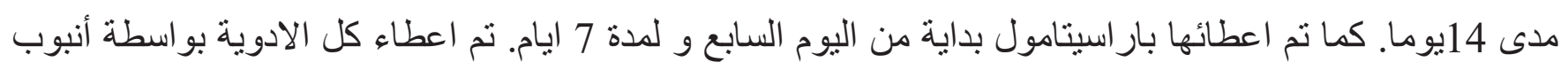
أنفي معدي. و في نهاية التجربة ، تم أخذ عينات الكبد وتجهيز ها للار اسات الهستولوجيه و الهرتو كيميائيه وسحب عينات الدم .كما تم عمل التحليل الإحصائي للنتائج. النتائج: تناول مستخلص المورينجا أوليفير اللمجمو عة الثانية لم يؤثر في بنية الكبدو خلاياه. حيث أن مقاطع الكبد كانت تقريبا مشابهة للمجموعة الضابطة. و قد تأكد ذلك بإختبار ات وظائف الكبد التي لم تظهر تغير عن المجمو عة الضابطة. إضافة إلى ذللك كان هناك زيادة ذو دلالة إحصائية في نشاط الجلوناثيون بير أكسيديز و الكاتاليز و لم يكن هناك تغير في

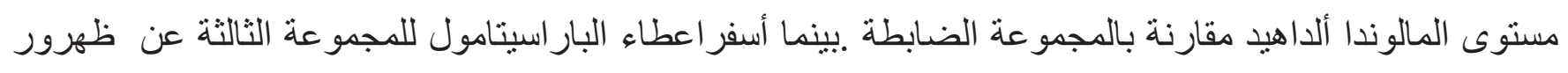
تجويفات بسيتوبلازم الخلايا الكبدية. تم ملاحظة احتقان وارتثاح خلوى حول الوريد البابي و الوريد المركزى. و كان هناك زيادة ذو دلالة إحصائية في النسبة المئوية لمساحة الألياف الكو لاجين مقارنة بالمجمو عة الضابطة بينما نقصت النسبة المئوية لمساحة الحبييات المصبوغة بال PAS نقصانا ذو دلالة إحصائية. فحص خلايا الكبد بالميكروسكوب لفالئه الإلكتروني أظهر وجود ميتو كندريا طويلة ومشو هة ونقصان ملحوظ في الثبكة الاندوبلاز ميه الخشنة مع زيادة ملحوظة في الثبكة الاندوبلازميه الناعمة. بالإضافة إلى أن الخلاية النجمية الكبدية مع ألياف الكو لاجين ظهرت بكثرة بين خلايا الكبد. تناول مستخلص أوراق المورينجا أوليفير ا قبل البار اسيتامول ,في المجموعة الرابعة،قد أدى إلى تقليل الأثار

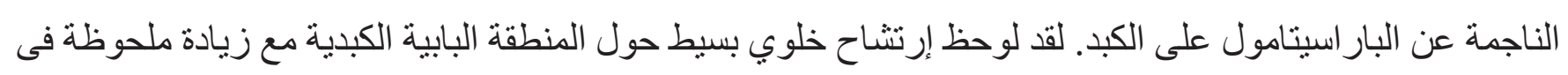
عدد الخلايا المبطنة للقنوات المرارية 
الاستتتاج: مستخلص أوراق المورينجا أوليفير اله دور وقائى على الكبد ضد تأثنير ات البار اسيتامول، و ذلك لقدرته على تثبيط أكسدة الدهون و تحفيز الإنزيمات المضادة للأكسدة. 